\title{
Insights into the role of major bioactive dietary nutrients in lamb meat quality: a review
}

\author{
Javier Álvarez-Rodríguez ${ }^{1 *}$ (D), Olaia Urrutia ${ }^{2}$, Sandra Lobón ${ }^{3,4}$, Guillermo Ripoll ${ }^{3,4}$, Juan Ramón Bertolín ${ }^{3,4}$ and \\ Margalida Joy ${ }^{3,4^{*}}$
}

\begin{abstract}
Feed supplementation with a-linolenic acid (ALA) and linoleic acid (LA) increases their content in muscle, ALA increases $n-3$ polyunsaturated fatty acids and decrease $n-6 / n-3$ ratio in muscle, and LA increases rumenic acid. However, high LA supplementation may have negative effects on lambs' lipid oxidative stability of meat. When the sources of ALA and LA are fed as fresh forage, the negative effects are counterbalanced by the presence of other bioactive compounds, as vitamin E (mainly a-tocopherol) and polyphenols, which delay the lipid oxidation in meat. There is a wide consensus on the capability of vitamin E delaying lipid oxidation on lamb meat, and its feed content should be adjusted to the length of supplementation. A high dietary inclusion of proanthocyanidins, phenolic compounds and terpenes reduce the lipid oxidation in muscle and may improve the shelf life of meat, probably as a result of a combined effect with dietary vitamin E. However, the recommended dietary inclusion levels depend on the polyphenol type and concentration and antioxidant capacity of the feedstuffs, which cannot be compared easily because no routine analytical grading methods are yet available. Unless phenolic compounds content in dietary ingredients/supplements for lambs are reported, no specific association with animal physiology responses may be established.
\end{abstract}

Keywords: Fatty acid, Forage, Oilseed, Polyphenol, Vitamin E

\section{Introduction}

Bioactive compounds are substances which are present in foods in small amounts and have the ability to provide health benefits. Bioactive compounds include, but are not limited to, long-chain polyunsaturated fatty acids (PUFA), vitamins, carotenoids, peptides, and polyphenols, and their applications have been discussed in poultry and swine nutrition [1]. The interest in these dietary nutrients in sheep has increased over the last years, but it would be necessary to evaluate if these

\footnotetext{
*Correspondence: javier.alvarez@udl.cat; mjoy@cita-aragon.es

'Departament de Ciència Animal, Universitat de Lleida, 25198 Lleida, Spain

${ }^{3}$ Centro de Investigación y Tecnología Agroalimentaria de Aragón (CITA),

Avda. Montañana 930, 50059 Zaragoza, Spain

Full list of author information is available at the end of the article
}

expected animal health benefits are also highlighted in meat quality.

Whilst the main sheep producers (China, Australia and New Zealand) raise heavy lambs yielding $17-23 \mathrm{~kg}$ carcass, some Mediterranean countries raise much smaller suckling and light lambs with $6-12 \mathrm{~kg}$ carcass [2]. The specific role of some bioactive nutrients in the feed sources on lamb meat quality may vary according to the feedstuffs and type of lamb production. This review aimed at evaluating the role of dietary unsaturated fatty acids (FA) and vitamins $\mathrm{E}$, and polyphenols on lamb performance, color, FA profile and its pro- and anti- oxidant markers of meat.

(C) The Author(s). 2022 Open Access This article is licensed under a Creative Commons Attribution 4.0 International License, which permits use, sharing, adaptation, distribution and reproduction in any medium or format, as long as you give appropriate credit to the original author(s) and the source, provide a link to the Creative Commons licence, and indicate if changes were made. The images or other third party material in this article are included in the article's Creative Commons licence, unless indicated otherwise in a credit line to the material. If material is not included in the article's Creative Commons licence and your intended use is not permitted by statutory regulation or exceeds the permitted use, you will need to obtain permission directly from the copyright holder. To view a copy of this licence, visit http://creativecommons.org/licenses/by/4.0/ The Creative Commons Public Domain Dedication waiver (http://creativecommons.org/publicdomain/zero/1.0/) applies to the data made available in this article, unless otherwise stated in a credit line to the data. 


\section{Unsaturated fatty acids}

Ruminant meat is characterised by having a considerable percentage of saturated fatty acids, because PUFA from diet are subjected to a process of biohydrogenation conducted by ruminal microorganisms, thus the FA profile of the meat differs from that of in the diet. However, lamb meat presents low $n-6 / n-3$ ratio compared with other meats such as pork and chicken (1.2 vs. 6.4 and 5.0, respectively) [3]. Also, it is an interesting source of conjugated linoleic acid (CLA), in particular the isomer cis-9, trans-11 (also called rumenic acid, RA), and $\alpha-$ linolenic acid (ALA, C18:3 n-3) and its elongation products. These FA have been related to the development of brain fetuses, the prevention of cardiovascular diseases and the reduction of carcinogenesis, atherosclerosis, the onset of diabetes and body fat mass $[4,5]$.

In the last decade, the use of dietary sources rich in PUFA, especially those of n-3 family, in lamb diets is of great interest, as a means to obtain a product more strongly fitted with the current human nutritional recommendations [6]. Various feeds, including oilseeds or plant and marine oils, have been investigated to improve the FA profile of lamb meat. These supplements are commonly rich in ALA (e.g. linseed, chia seed, camelina oil), linoleic acid (LA, C18:2 n-6) (e.g. corn oil, sunflower and safflower), eicosapentaenoic acid (EPA, C20:5 n-3) and docosahexaenoic acid (DHA, C22:6 n-3) (e.g. marine algae and fish oil) or oleic acid (OA, C18:1 cis-9) (e.g. canola/rapeseed and olive oil) [7].

Among ALA-rich sources, linseed (Linum usitatissimum) is one of the most studied feed ingredients. It contains ALA (around 56\%), LA and OA (16\% each) and saturated fatty acids $(9.5 \%)$ [8, 9]. Chia seed (Salvia hispanica L.) is another novel feed that has been receiving attention because of its high ALA content. It includes up to $64 \%$ of ALA, LA (19\%) and OA $(9 \%)[8,10]$. Alternatively, the primary sources of EPA and DHA are marine oils derived from fish or algae. For livestock feeding, the most important microalgae species are Arthrospira platensis, Chlorella sp., Isochrysis sp., Porphyridium sp., and Schizochytrium sp., the latter being mostly used $[11,12]$.

The inclusion of ALA-rich sources (linseed, chia seed and camelina oil) did not affect growth and carcass parameters, either in light $[1,2,13,14]$ or heavy lambs [15-17]. Similar results were observed when LA-rich sources (sunflower and safflower) were included between $2 \%$ and $15 \%$ in the diet [18-20], but the dry matter intake (DMI) tended to reduce with $15 \%$ of safflower inclusion [20]. In that sense, Oliveira et al. [21] observed that the inclusion of $30 \%$ of crushed sunflower caused a reduction of average daily gain (ADG) in heavy lambs, and worsen carcass characteristics. As pointed out by Nguyen et al. [9], high levels of fat in ruminant diets can result in negative effects on growth performance reducing DMI, due to a decrease in feed palatability, fiber digestibility and digestive nutrient flows. On the other hand, the results obtained about the inclusion of algae or fish oil are not conclusive. When algae ( $2 \%$ and $3.9 \%)$ or fish oil (3.3\%) were included in the diet, studies showed a negative effect on lamb performance, with lower ADG and DMI and higher feed conversion ratio $[1,14,22,23]$ and lower carcass weights [14] than lambs fed the control diet. In contrast, there was no effect of inclusion of $1.9 \%$ [24], 3\% [25] and 4\% [14] of algae and $1.5 \%$ of fish oil [23] on lamb productive parameters.

The effects of dietary PUFA supplementation on meat quality characteristics of lambs are summarised in Table 1. The aim of supplementation of ALA-rich sources is to promote its content in Longissimus thoracis et lumborum (LTL) muscle of light and heavy lambs.

Overall, the results of the reviewed studies revealed that the inclusion of ALA-rich sources (linseed, chia seed and camelina oil) in the diet enhance ALA content in LTL muscle of light and heavy lambs. Consequently, total n-3 PUFA increased and n-6/n-3 ratio decreased significantly. Regarding EPA content in LTL muscle, findings are controversial, with some studies reporting no increase of EPA in lambs fed with ALA-rich sources and others reporting some signs of ALA elongation and desaturation, with increased EPA in light $[1,2,14]$ and heavy lambs $[16,17]$. However, most studies have reported that muscle levels of DHA did not increase, which could be the result of the limited conversion of ALA to their long chain products [29, 30]. Thus, the most effective strategy to enrich lamb meat in long chain PUFA, primarily DHA, may be the use of algae or fish oil in the diet [11]. Hopkins et al. [24] evaluated the inclusion of $1.95 \mathrm{~g} / \mathrm{kg}$ of Schizochytrium sp. algae in LTL muscle of heavy lambs and observed an increase of 0.5fold in EPA and 4.9-fold in DHA, which correspond to a value of $147.7 \mathrm{mg}$ of the sum of EPA + DHA/100 $\mathrm{g}$ of meat.

Concerning OA content, some studies have reported a decrease in LTL muscle when ALA-rich sources are fed in light $[1,13,22]$ and heavy lambs [15-17]. This may be attributed to the presence of high contents of dietary PUFA that inhibit the stearoyl-CoA desaturase (SCD) gene expression, as this gene encodes the enzyme responsible for the synthesis of OA from stearic acid (C18: 0 ) and also RA derived from vaccenic acid (VA, C18:1 trans-11) [16, 32]. It has been suggested that dietary PUFA modulate the expression of genes involved in lipid metabolism, changing the adipocyte metabolism toward promoting dietary fatty acid uptake and activating the fatty acid oxidation, and downregulating de novo fatty acid synthesis acting on the expression of genes such as acetyl-CoA desaturase $(A C A C A)$, fatty acid synthase $(F A S N)$ or $S C D[25,32]$. 
Table 1 The effect of different sources of polyunsaturated fatty acid (PUFA) supplementation on meat quality characteristics of Longissimus dorsi in lambs

\begin{tabular}{|c|c|c|c|c|c|c|c|c|c|c|c|c|c|c|c|}
\hline \multirow[t]{2}{*}{ Concentrate basal diet ${ }^{2}$} & \multirow[t]{2}{*}{ PUFA source ${ }^{3}$} & \multirow[t]{2}{*}{ Level, \% } & \multicolumn{6}{|c|}{ Fatty acid profile ${ }^{4}$} & \multirow{2}{*}{$\begin{array}{l}\text { Oxidation, } \\
\text { TBARS }^{4}\end{array}$} & \multicolumn{5}{|c|}{ Sensory quality ${ }^{4}$} & \multirow[t]{2}{*}{ Ref. } \\
\hline & & & ALA & EPA & DHA & LA & OA & RA & & Tend. & Juic. & Odor & Flavor & $\mathrm{OL}$ & \\
\hline \multicolumn{16}{|c|}{ Light lambs (<24 kg body weight) } \\
\hline Barley/soybean & Ext. linseed & 5 & $\uparrow 1.0$ & $=$ & $=$ & $=$ & $=$ & $=$ & NR & NR & NR & NR & NR & $N R$ & [1] \\
\hline Barley/soybean & Ext. linseed & 10 & $\uparrow 1.4$ & $=$ & $=$ & $\downarrow 0.2$ & $=$ & $=$ & NR & NR & NR & NR & NR & NR & [1] \\
\hline Barley/soybean & Ext. linseed & 10.5 & $\uparrow 2.8$ & $\uparrow 1.2$ & $=$ & $=$ & $\downarrow 0.1$ & $=$ & NR & NR & NR & NR & NR & NR & [1] \\
\hline Barley/soybean & Chia seed & 10 & $\uparrow 2.3$ & $\uparrow 0.9$ & $=$ & $=$ & $\downarrow 0.1$ & $=$ & $N R$ & $N R$ & NR & NR & $N R$ & NR & [1] \\
\hline Barley/soybean & Ext. linseed & 15 & $\uparrow 2.1$ & $\uparrow 2.9$ & NR & $=$ & $=$ & NR & NR & NR & NR & NR & NR & NR & [2] \\
\hline Barley/soybean & Ext. linseed & 30 & $\uparrow 2.2$ & $\uparrow 2.6$ & NR & $=$ & $=$ & $N R$ & $N R$ & NR & NR & NR & $N R$ & NR & [2] \\
\hline Barley/soybean & Ext. linseed & 10 & $\uparrow 3.6$ & $\uparrow 2.9$ & $=$ & $=$ & $\downarrow 0.1$ & $=$ & $=$ & $=$ & $=$ & $=$ & $=$ & $=$ & [13] \\
\hline Barley/soybean & Ext. linseed+algae $e^{5}$ & $5+3.9$ & $\uparrow 1.2$ & $\uparrow 4.3$ & $\uparrow 18.8$ & $=$ & $\downarrow 0.3$ & $=$ & $\uparrow 0.86$ & $=$ & $=$ & $\downarrow 0.2$ & $\downarrow 0.2$ & $\downarrow 0.2$ & [13] \\
\hline Barley/wheat & Ext. linseed & 12.5 & $\uparrow 5.6$ & $\uparrow 2.5$ & $=$ & $=$ & $=$ & $N R$ & $=$ & $=$ & $=$ & $\downarrow 0.2$ & $\downarrow 0.1$ & $=$ & [14] \\
\hline Barley/wheat & Ext. linseed+algae & $10.7+4$ & $\uparrow 3.7$ & $\uparrow 2.1$ & $\uparrow 1.8$ & $=$ & $=$ & NR & $\uparrow 2.1$ & $=$ & $=$ & $\downarrow 0.2$ & $\downarrow 0.1$ & $=$ & [14] \\
\hline Barley/wheat & Fish oil & 3.3 & $=$ & $\uparrow 9.6$ & $\uparrow 11.0$ & $\downarrow 0.3$ & $=$ & $N R$ & $\uparrow 4.0$ & $=$ & $=$ & $\downarrow 0.3$ & $\downarrow 0.3$ & $\downarrow 0.4$ & [14] \\
\hline Barley/wheat & Algae $^{6}$ & 2 & $=$ & $\uparrow 6.6$ & $\uparrow 12.4$ & $=$ & $\downarrow 0.1$ & $=$ & NR & NR & NR & NR & NR & NR & [22] \\
\hline Barley/soybean & Sunflower oil & 4 & $\downarrow 0.3$ & $=$ & $=$ & $=$ & $=$ & $=$ & NR & $N R$ & NR & NR & $N R$ & $N R$ & [26] \\
\hline \multicolumn{16}{|c|}{ Heavy lambs (> 24 kg body weight) } \\
\hline Barley/corn & Ext. linseed & 3 & $\uparrow 1.2$ & $=$ & $=$ & $=$ & $=$ & $=$ & NR & NR & NR & NR & $N R$ & NR & [27] \\
\hline Wheat/triticale & Ext. linseed & 3 & $\uparrow 1.0$ & $=$ & $=$ & $=$ & $\downarrow 0.1$ & $=$ & $N R$ & $N R$ & NR & NR & $N R$ & NR & [15] \\
\hline Wheat/triticale & Ext. linseed & 6 & $\uparrow 1.3$ & $=$ & $=$ & $=$ & $=$ & $=$ & NR & NR & NR & NR & NR & NR & [15] \\
\hline Wheat/triticale & Ext. linseed & 9 & $\uparrow 2.5$ & $=$ & $=$ & $=$ & $\downarrow 0.1$ & $=$ & $N R$ & $N R$ & $N R$ & $N R$ & $N R$ & NR & [15] \\
\hline Barley/soybean & Linseed oil & 4.8 & $\uparrow 1.8$ & $\uparrow 0.9$ & $\uparrow 0.5$ & $=$ & $\downarrow 0.3$ & $=$ & NR & NR & NR & NR & NR & NR & [16] \\
\hline Barley/beet & Linseed oil & 6 & $\uparrow 2.5$ & $\uparrow 0.7$ & $=$ & $=$ & $\downarrow 0.1$ & $=$ & $N R$ & $N R$ & $N R$ & $N R$ & $N R$ & $N R$ & [17] \\
\hline Barley/beet & Camelina oil & 6 & $\uparrow 1.5$ & $\uparrow 0.6$ & $=$ & $=$ & $\downarrow 0.1$ & $=$ & NR & $N R$ & $N R$ & $N R$ & $N R$ & $N R$ & [17] \\
\hline Barley/wheat & Fish oil & 3 & $\uparrow 0.8$ & $\uparrow 3.0$ & $\uparrow 4.6$ & $=$ & $=$ & $N R$ & NR & NR & NR & NR & $N R$ & NR & [23] \\
\hline Barley/wheat & Canola oil & 3 & $\uparrow 1.4$ & $\uparrow 0.4$ & $=$ & $=$ & $\uparrow 0.2$ & $N R$ & NR & $N R$ & NR & NR & NR & NR & [23] \\
\hline Barley/wheat & Fish oil+canola oil & $1.5+1.5$ & $\uparrow 0.9$ & $\uparrow 2.8$ & $\uparrow 2.5$ & $\uparrow 0.7$ & $=$ & NR & NR & NR & NR & NR & NR & $N R$ & [23] \\
\hline Commercial & Canola oil & $150^{7}$ & $=$ & $\uparrow 1.1$ & $=$ & $=$ & $\uparrow 0.5$ & $\uparrow 1.5$ & NR & NR & NR & NR & $N R$ & $N R$ & [28] \\
\hline Soybean/barley & Canola oil+fish oil & $2+1$ & NR & $=$ & $\uparrow 0.8$ & NR & NR & $\uparrow 1.9$ & NR & $\downarrow 0.3$ & $=$ & $=$ & $=$ & $\downarrow 0.2$ & [29] \\
\hline Wheat/barley ${ }^{8}$ & Fish oil & 4.3 & $\downarrow 0.8$ & $\uparrow 0.5$ & $\uparrow 0.7$ & $\downarrow 0.3$ & $=$ & $\downarrow 0.4$ & $\uparrow 7.39$ & $N R$ & $=$ & $N R$ & $\downarrow 0.2$ & $\downarrow 0.4$ & [30] \\
\hline Wheat/barley ${ }^{8}$ & Fish oil+algae ${ }^{10}$ & $2.1+1.6$ & $\downarrow 0.8$ & $\uparrow 1.3$ & $\uparrow 3.7$ & $\downarrow 0.2$ & $\downarrow 0.2$ & $\downarrow 0.5$ & $\uparrow 9.09$ & $N R$ & $=$ & NR & $\downarrow 0.3$ & $\downarrow 0.2$ & [30] \\
\hline Corn/wheat & Algae $^{5}$ & 3 & $=$ & $\uparrow 5.5$ & $\uparrow 15.8$ & $\downarrow 0.2$ & $=$ & $\uparrow 0.9$ & NR & $N R$ & NR & NR & $N R$ & NR & [25] \\
\hline Oat/lupin grain & Algae $^{5}$ & 1.95 & $=$ & $\uparrow 0.5$ & $\uparrow 4.9$ & $=$ & $\downarrow 0.2$ & $N R$ & $\uparrow 2.5$ & $N R$ & $N R$ & $N R$ & $N R$ & NR & [24] \\
\hline Corn/soybean & Sunflower cake & 10 & $=$ & $=$ & NR & $\uparrow 0.6$ & $\downarrow 0.1$ & $\uparrow 0.6$ & NR & $\uparrow 0.1$ & $\uparrow 0.2$ & NR & $\uparrow 0.1$ & $=$ & [21] \\
\hline Corn/soybean & Sunflower cake & 20 & $=$ & $=$ & $N R$ & $\uparrow 0.6$ & $\downarrow 0.1$ & $\uparrow 0.6$ & NR & $\uparrow 0.1$ & $\uparrow 0.2$ & NR & $\uparrow 0.2$ & $=$ & [21] \\
\hline Corn/soybean & Sunflower cake & 30 & $=$ & $=$ & NR & $\uparrow 1.0$ & $\downarrow 0.2$ & $\uparrow 0.9$ & $N R$ & $\uparrow 0.2$ & $\uparrow 0.2$ & NR & $\uparrow 0.2$ & $=$ & [21] \\
\hline Barley/palm & Sunflower oil & 2 & NR & NR & NR & $=$ & $\uparrow 0.1$ & $=$ & $N R$ & $N R$ & NR & NR & NR & $N R$ & [18] \\
\hline Barley/palm & Sunflower oil & 4 & $N R$ & NR & NR & $\uparrow 0.2$ & $\uparrow 0.1$ & $\uparrow 1.0$ & NR & $N R$ & $N R$ & $N R$ & $N R$ & $N R$ & [18] \\
\hline Corn/soybean & Safflower oil & 7.5 & $=$ & $=$ & $=$ & $=$ & $=$ & $=$ & NR & $N R$ & NR & NR & $N R$ & $N R$ & [20] \\
\hline Corn/soybean & Safflower oil & 15 & $=$ & $=$ & $=$ & $=$ & $=$ & $=$ & $N R$ & $N R$ & $N R$ & $N R$ & $N R$ & $N R$ & [20] \\
\hline Corn/wheat & Safflower oil & 3 & $=$ & $=$ & $=$ & $=$ & $\downarrow 0.2$ & $\uparrow 0.6$ & NR & NR & NR & NR & NR & NR & [19] \\
\hline
\end{tabular}


Table 1 The effect of different sources of polyunsaturated fatty acid (PUFA) supplementation on meat quality characteristics of Longissimus dorsi in lambs (Continued)

\begin{tabular}{|c|c|c|c|c|c|c|c|c|c|c|c|c|c|c|c|}
\hline \multirow[t]{2}{*}{ Concentrate basal diet ${ }^{2}$} & \multirow[t]{2}{*}{ PUFA source ${ }^{3}$} & \multirow[t]{2}{*}{ Level, \% } & \multicolumn{6}{|c|}{ Fatty acid profile ${ }^{4}$} & \multirow{2}{*}{$\begin{array}{l}\text { Oxidation, } \\
\text { TBARS }^{4}\end{array}$} & \multicolumn{5}{|c|}{ Sensory quality ${ }^{4}$} & \multirow[t]{2}{*}{ Ref. } \\
\hline & & & ALA & EPA & DHA & LA & $O A$ & $\mathrm{RA}$ & & Tend. & Juic. & Odor & Flavor & $\overline{\mathrm{OL}}$ & \\
\hline Corn/wheat & Safflower oil & 6 & $=$ & $=$ & $=$ & $=$ & $\downarrow 0.3$ & $\uparrow 1.3$ & NR & NR & $N R$ & $N R$ & NR & NR & [19] \\
\hline Barley/corn & Safflower oil & 6 & $\downarrow 0.3$ & NR & NR & $\uparrow 0.5$ & $\downarrow 0.1$ & $\uparrow 1.1$ & NR & NR & $N R$ & NR & NR & NR & [31] \\
\hline
\end{tabular}

Effects are shown as relative variation with respect to the control diet and expressed in the fold change. ALA a-linolenic acid, DHA docosahexaenoic acid, EPA eicosapentaenoic acid, Ext. linseed extruded linseed, IMF intramuscular fat, Juic. Juiciness, LA linoleic acid, NR Not reported, OA oleic acid, OL overall liking, $R A=$ rumenic acid; $T B A R S=$ thiobarbituric acid reactive substances; Tend.$=$ Tenderness

${ }^{1} 1$-fold increase means $100 \%$ increase (it doubles)

${ }^{2}$ Main components of the concentrate are presented

${ }^{3}$ PUFA sources: ALA-rich = linseed, chia and camelina; LA-rich = sunflower and safflower; EPA/DHA-rich = algae and fish oil, OA-rich = canola

${ }^{4}$ Arrows indicate up $(\uparrow)$ or down $(\downarrow)$ significant values compared to control. Almost equal sign $(=)$ symbolize no change between control and PUFA-rich diet ${ }^{5}$ DHA-Gold (Market Biosciences Corp., Columbia, MD, USA). Algal meal high in DHA derived from Schizochytrium spp. In Fan et al. [25] the algal meal is algae powder (Schizochytrium sp.; Xiamen Huison biotech Co., Ltd., Xiamen, China)

${ }^{6}$ TBARS were analysed in meat after $4 \mathrm{~d}$ display in Urrutia et al. [1] and Hopkins et al. [24] and after $7 \mathrm{~d}$ display in de la Fuente-Vázquez et al. [14] and Nute et al. [30]

${ }^{7}$ The inclusion level of canola oil was $50 \mathrm{~mL} / \mathrm{d}$, three times per week (150 mL/week)

${ }^{8}$ The effect of PUFA in this work is expressed as changes compared to the linseed oil supplemented group

${ }^{9}$ Lipid oxidation was assessed in Semimembranosus muscle

${ }^{10}$ Algae from a dinoflagellate of the class Dinophyceae (Martek Biosciences Corp., Columbia, MD, USA)

The enrichment of meat with PUFA that is beneficial from a point of human health view, affects the oxidative stability of meat, if the presence of some antioxidant compound, as vitamin E, is not adequate [33]. Lipid oxidation can influence key quality attributes, including color, texture, taste and aroma leading to rancidity and off-flavors, which ultimately affect meat acceptance [34]. There are not many studies examine the correlation between PUFA levels and meat lipid oxidation rates in lambs. Urrutia et al. [13] and de la Fuente-Vázquez et al. [14] reported that meat from light lambs supplemented with linseed (10\% and $12.5 \%$, respectively) did not exhibit lower oxidative stability in LTL muscle compared to controls, with concentrations of malondialdehyde (MDA) below $2 \mathrm{mg} / \mathrm{kg}$ of meat, which is reported to be the cut off value above which rancidity may be detected by consumers de la Fuente-Vázquez et al. [14]. In contrast, the partial substitution of linseed with algae (3.9 and $4 \%$ of algae, respectively) in the diet, significantly increased the lipid oxidation measured as Thiobarbituric Acid Reactive Substances (TBARS) levels. Similarly, Nute et al. [30] observed in heavy lambs fed algae produced the most lipid unstable meat on $\mathrm{d} 7$ with a 9-fold increase in TBARS value, followed by that induced fish oil supplementation with 7.3-fold. The potential causes of the different effect of linseed and algae can be attributed to a high ALA content, which is susceptible to oxidation, but less than the EPA and DHA [35]. Also, it is known that plant oils as linseed contain antioxidants and increased $\alpha$-tocopherol concentrations in muscle, preventing lipid oxidation [36].

The color of meat can be also affected by the high contents of some PUFAs. The inclusion of EPA and DHArich sources (fish oil and algae) in the diet, resulted in less lipid and color stability of meat during retail display [14,
30]. The latest authors reported that less red meat would be the consequence of increased metmyoglobin, caused by higher lipid oxidation due to higher $\mathrm{n}-3$ long chain PUFA content in the diets. In contrast, linseed [2, 14, 27], canola oil [37], sunflower [21, 38] and safflower oil [19] dietary supplementation did not affect meat color parameters. Moreover, it has been found that redness increased when $15 \%$ of safflower oil [20] or $150 \mathrm{~mL} /$ week canola oil [28] were supplemented, which can be related to the increased intake of $\alpha$-tocopherol from safflower oil and of monounsaturated fatty acids (MUFA) from canola fed animals, acting as limiting factor for lipid oxidation of meat.

The use of oilseed or plant and marine oils in the diet can influence sensory properties of meat [9]. Results from literature are not conclusive. The meat tenderness and juiciness were not affected by different PUFA-rich sources [13, 22, 30]. Despite this, Lima et al. [39] reported improved tenderness, juiciness and flavor when sunflower cake was included up to $30 \%$ in lambs' diet. In contrast, $1 \%$ of fish oil addition was associated with low values for tenderness, resulting in the lowest overall sensory quality [29]. Generally, the use of fish oil and algae in the diet reduced the ratings for lamb odor, flavor and overall liking and increased fishy flavor, which was linked to the high proportion of EPA and DHA [13, 22, 30]. The inclusion of fish oil or marine algae up to $4 \%$ is the most effective strategy to improve $\mathrm{n}-3$ long chain PUFA levels as EPA and DHA, however, it can negatively affect lamb performance and meat quality, with less appealing meat in terms of color, lipid oxidation and flavor.

In the last decades, the interest to reintroduce fresh forage in ruminant diets is increasing, since it is in line with the demands of consumers for animal products from natural, healthy and sustainable systems. Forages are naturally rich in ALA, and their intake can improve 
its deposition in lamb meat and therefore increase the PUFA content. There are many factors that can influence FA content of forages, such as the species, vegetation stage, conditions of conservation and $\mathrm{N}$ fertilization [40], with vegetation stage being the predominant factor.

Table 2 summarizes the amount of FA present in forages and consequently in lamb meat reported by several authors. The FA profile of forage influences the type of FA deposit on lamb meat. The natural pasture and legume forages present high amount of n-3 PUFA and, although they are subjected to ruminal biohydrogenation, partial amount of dietary unsaturated FA escape the rumen. Therefore, lambs fed with forages rich in n-3 PUFA present high content of these FA in meat and consequently the ratio $n-6: n-$ 3 is lower (Table 2). In contrast to other sources of PUFA, feeding forage does not increase lipid oxidation of meat (Table 2) as consequence of the presence of some bioactive compounds in the forages, as vitamin $\mathrm{E}$ (mainly $\alpha$-tocopherol) and polyphenols, that act as natural antioxidants and can be transferred to the meat.

\section{Vitamin E}

Vitamin E is synthesized only by plants, some algae and cyanobacteria [45], therefore, animals assimilate vitamin $\mathrm{E}$ from the diet. Vitamin $\mathrm{E}$ acts as a chain breaking antioxidant because is not degraded in the rumen, but it is accumulated within the lipid bilayers of cellular membrane increasing antioxidant potential [46]. There is a wide consensus that supra-nutritional vitamin $\mathrm{E}$ does not improve growth performance or carcass characteristics of light lambs [47-51], but its presence is a very useful way to delay the color fading, off-odors formation and lipid oxidation protecting PUFA and proteins from oxidation [48-52].

The magnitude of the effect of vitamin $\mathrm{E}$ depends on its concentration in muscle, which in turn depends on the content and chemical form of vitamin $E$ ingested, the length of the feeding period and the kind of animal (light or heavy lamb). Since the 90's it is known that supplementation of at least $1000 \mathrm{mg} / \mathrm{kg}$ with $\alpha$ tocopherol to the lambs is effective in improving meat color and shelf-life stability [53], but every year new papers and reviews about supra-nutritional doses of vitamin $\mathrm{E}$ are still being published. Adjusting the

Table 2 Fatty acid composition of dietary forages and lamb meat (g FA/100 of total FA), and lipid oxidation (TBARS, mg MDA/kg of meat) of lamb meat

\begin{tabular}{|c|c|c|c|c|c|c|c|c|c|c|}
\hline \multirow[t]{2}{*}{ Treatment } & \multirow[t]{2}{*}{ Lamb type $^{4}$} & \multicolumn{4}{|c|}{$\begin{array}{l}\text { Fatty acid profile } \\
\text { of forage }\end{array}$} & \multicolumn{3}{|c|}{$\begin{array}{l}\text { Fatty acid profile } \\
\text { of meat }\end{array}$} & \multirow[t]{2}{*}{ Oxidation, TBARS $^{5}$} & \multirow[t]{2}{*}{ Ref. } \\
\hline & & C16:0 & $\mathrm{OA}$ & LA & ALA & LA & n-3 PUFA & $n-6: n-3$ & & \\
\hline Mountain Pasture & Suckling & 14.8 & 3.9 & NR & 51.9 & 2.5 & 7.0 & 2.0 & $1.20(9 \mathrm{~d})$ & {$[41]$} \\
\hline Hay pasture & Suckling & 16.5 & 9.0 & NR & 31.0 & 1.38 & 5.0 & 2.9 & $1.49(9 \mathrm{~d})$ & \\
\hline Sainfoin (Onobrichis vicifolia) & Light & 23.4 & 3.5 & 18.5 & 35.6 & 1.5 & 3.4 & 4.3 & $1.55(14 \mathrm{~d})$ & [42] \\
\hline Alfalfa (Medicago sativa) & Light & 24.7 & 3.5 & 16.3 & 40.8 & 1.4 & 2.4 & 3 & $1.96(14 \mathrm{~d})$ & \\
\hline Total mixed ration ${ }^{1}$ & Light & 31.2 & 23.1 & 26.6 & 2.8 & 0.5 & 1.3 & 7 & $2.36(14 \mathrm{~d})$ & \\
\hline Lowland ${ }^{2}$ & Heavy & 16.3 & 2.8 & 0.1 & 49.7 & 2.18 & NR & 1.88 & NR & [43] \\
\hline Alpine $^{3}$ & Heavy & 15.5 & 3.7 & 0.1 & 48.6 & 3.21 & NR & 1.7 & NR & \\
\hline Alfalfa (Medicago sativa) silage & Heavy & 18.5 & 2.7 & 19.6 & 36.2 & 2.9 & 1.3 & NR & NR & {$[44]$} \\
\hline Red colver (Trifolium pratense) silage & Heavy & 15.1 & 3.4 & 18.1 & 40.2 & 3 & 1.1 & NR & NR & \\
\hline Birdsfoot refoil silage & Heavy & 15.5 & 3.9 & 17.3 & 43.0 & 2.5 & 1.6 & NR & NR & \\
\hline Sainfoin (Onobrichis vicifolia) silage & Heavy & 17.2 & 3.6 & 15.0 & 43.4 & 4.6 & 1.2 & NR & NR & \\
\hline Bladder cover (Trifolium spumosum) & Heavy & NR & NR & NR & 12.0 & 3.8 & 8.7 & 1.8 & $3.1(12 d)$ & [33] \\
\hline Brassica (Brassica napus) & Heavy & NR & NR & NR & 32.4 & 4.7 & 9.5 & 1.5 & $2.6(12 d)$ & \\
\hline $\begin{array}{l}\text { Chicory (Cichorium intybus) + arrow leaf clover } \\
\text { (Trifolium vesiculosum) }\end{array}$ & Heavy & NR & NR & NR & 40.4 & 5.1 & 10.1 & 1.5 & $3(12 d)$ & \\
\hline Alfalfa (Medicago sativa) + Phalaris (Phalaris aquatica) & Heavy & NR & NR & NR & 42.2 & 4.3 & 9.3 & 1.6 & $2.6(12 d)$ & \\
\hline Alfalfa (Medicago sativa) & Heavy & NR & NR & NR & 29.4 & 4.6 & 9.5 & 1.5 & $3(12 d)$ & \\
\hline
\end{tabular}

ALA a-linolenic acid, FA Fatty Acid, LA Linoleic Acid, MDA Malonaldehyde, NR Not Reported, OA Oleic Acid, PUFA Polyunsaturated Fatty Acid, TBARS Thiobarbituric Acid Reactive Substances

${ }^{1} 50 \%$ barley straw, $11.6 \%$ corn, $11.5 \%$ barley, $9.3 \%$ legume, $7 \%$ rapeseed meal

${ }^{2} 60 \%$ grasses, $40 \%$ legumes

${ }^{3} 40 \%$ grasses, $20 \%$ legumes, $40 \%$ herbs

${ }^{4}$ Suckling is a $30-45$ days old lamb with $12-14 \mathrm{~kg}$, light is a $75-90$ days old lamb with $22-28 \mathrm{~kg}$, heavy is a $>120$ days old lamb with > $35 \mathrm{~kg}$ of body-weight at slaughter

${ }^{5}$ TBARS values and days (d) of exposure are expressed 
concentration of vitamin $\mathrm{E}$ and time of feeding remains challenging because vitamin $\mathrm{E}$ is highly effective but expensive. The use of vitamin $\mathrm{E}$ to delay meat oxidation has many advantages over other antioxidants, vitamin $\mathrm{E}$ is mainly stored close to PUFA in the polar lipid fraction of muscle (phospholipids), the readiness to donate a hydrogen molecule to a free radical, the easiness of its use and supplementation, it is not degraded in the rumen, and finally, it is a compound which is not rejected by consumers. This section focused on supranutritional doses included in the feed, excluding intravenous dosage and industry by-products that may include vitamin E. The supra-nutritional doses are greater than $30 \mathrm{mg} / \mathrm{kg}$ of feed, the minimum concentration of vitamin E needed to prevent white muscle disease [54].

The most important question is: how many vitamin $\mathrm{E}$ in the muscle is needed to delay meat oxidation and spoilage? However, the answer depends on the variable studied. For colour stability, Jose et al. [55] reported that the threshold was $3.5 \mathrm{mg}$ vitamin $\mathrm{E} / \mathrm{kg}$ of meat. Redox activity was unaffected when the vitamin $E$, ranging from 2.5 to $5.1 \mathrm{mg} / \mathrm{kg}$ of meat, although the highest concentration delayed lipid oxidation [56, 57] and even with only $1.9 \mathrm{mg}$ of vitamin E/kg of meat, Kasapidou et al. [58] observed a delay of lipid oxidation. The concentration of vitamin $\mathrm{E}$ in muscle required for the delay of the lipid oxidation varies between studies. López-Bote et al. [59] reported that the concentration of $5.4 \mathrm{mg}$ of vitamin $\mathrm{E} / \mathrm{kg}$ of meat was useful to control lipid oxidation, whereas Álvarez et al. [60] concluded that a concentration of $\alpha$-tocopherol between 1.87 and $2.37 \mathrm{mg} / \mathrm{kg}$ meat, was effective to reduce lipid and pigment oxidation during long periods of conservation. Ponnampalam et al. [61] concluded that increasing lamb meat vitamin E content $>3.45 \mathrm{mg} / \mathrm{kg}$ muscle will delay oxidation across long term storage periods.

It remains unclear how much vitamin $\mathrm{E}$ should be ingested to accumulate the desired vitamin $\mathrm{E}$ in muscle. Most of the cited studies provided the supra-nutritional doses and time of feeding but not the intake of lambs. The Fig. 1a shows the relationship between doses and concentration of vitamin $\mathrm{E}$ in muscle. There is no evident relationship between them, even considering the lamb body-weight. It can be supposed that heavy animals have more intramuscular fat and hence more vitamin E. However, Turner et al. [72] found a quadratic relationship between dietary vitamin $\mathrm{E}$ and muscle content, with a plateau around $5 \mathrm{mg}$ of vitamin $\mathrm{E} / \mathrm{kg}$ of meat, that was attained with a dietary vitamin $\mathrm{E}$ of approximately $400 \mathrm{mg} / \mathrm{kg}$ concentrate. Accordingly, Hampel et al. [52] carried out a meta-analysis of the relationship between tocopherol level in the diet and their effects on the quality of lamb meat. These authors reported that when dietary tocopherol levels were above
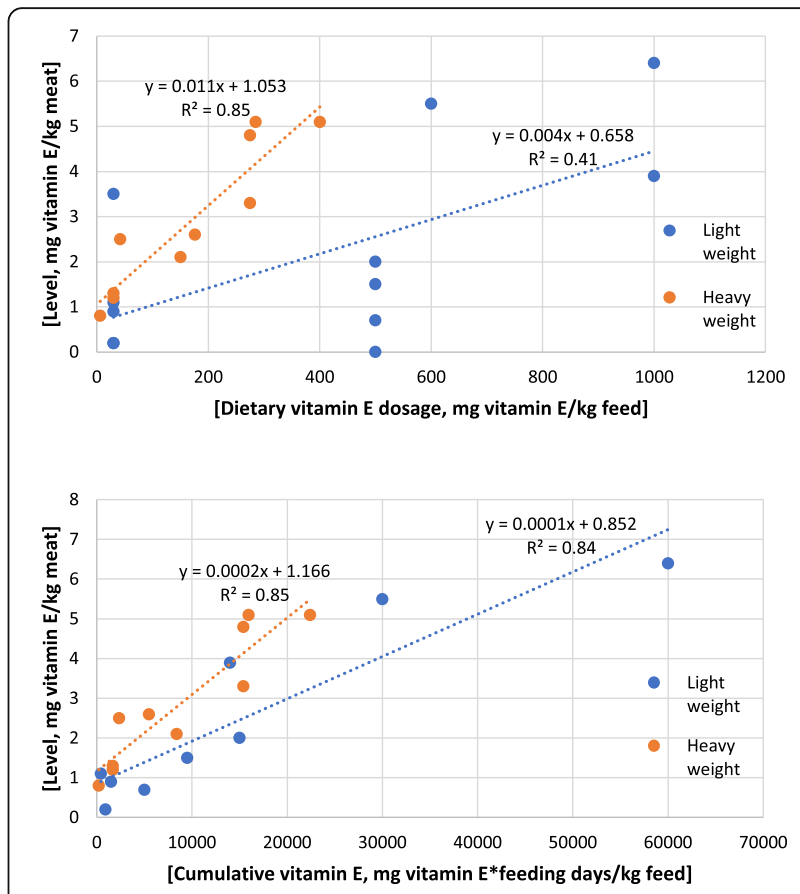

Fig. 1 Relationship between doses of vitamin $E$ (a) and days of feeding (b) with levels of vitamin $E$ in meat [based on [56, 62-71, 125-127]]

$400 \mathrm{mg} / \mathrm{kg}$ of feed, there was no significant increase in the concentration of $\alpha$-tocopherol in the meat. When both the time feeding lasted and dose supplemented is related to muscle content (Fig. 1b), the relationship is clearer although it could be either linear or quadratic, regardless of the slaughter weight of lambs.

Most of the studies have reported that supra-nutritional doses of vitamin $\mathrm{E}$ added to feedstuffs do not modify the proximal composition of meat but they indeed increase the vitamin $\mathrm{E}$ concentration in muscle. However, several studies on the effect of vitamin $\mathrm{E}$ against lipid oxidation reported effects, but it is difficult to compare them, due to the different doses and period of feeding vitamin $\mathrm{E}$, as well as the vitamin $\mathrm{E}$ concentration in muscle and the different time of display/oxygenation of meat.

De Almeida et al. [62] reduced the meat oxidation from 0.12 to $0.08 \mathrm{mg} \mathrm{MDA} / \mathrm{kg}$ meat without ageing or oxygenation but using a large feeding period $(75 \mathrm{~d})$ and great doses of vitamin E (1000 mg/kg of diet). GonzálezCalvo et al. [63] feeding light lambs with $500 \mathrm{mg}$ of vitamin $\mathrm{E} / \mathrm{kg}$ of concentrate, observed that lipid oxidation of meat was delayed until $7 \mathrm{~d}$ of display when the concentration of vitamin $\mathrm{E}$ in meat was greater than $0.61 \mathrm{mg} / \mathrm{kg}$ of meat, but below this value, lipid oxidation increased exponentially. Ripoll et al. [64] found that feeding lambs with $500 \mathrm{mg}$ of vitamin $\mathrm{E} / \mathrm{kg}$ of concentrate for $33 \mathrm{~d}$ was enough to keep a value of TBARS lower than $0.2 \mathrm{mg}$ $\mathrm{MDA} / \mathrm{kg}$ of meat for $13 \mathrm{~d}$ of time of display. The threshold of concentration of vitamin $\mathrm{E}$ in muscle to delay the 
formation of metmyoglobin from 5 to $7 \mathrm{~d}$ was $0.91 \mathrm{mg}$ vitamin $\mathrm{E} / \mathrm{kg}$ meat [63]. With the same dosage of vitamin E but administered during $50 \mathrm{~d}$, Ortuño et al. [65] decreased the oxidation from 4.6 to $0.4 \mathrm{mg} \mathrm{MDA} / \mathrm{kg}$ of meat when time of display to oxygen was $7 \mathrm{~d}$. The studies of Bellés et al. [66, 67] used $1000 \mathrm{mg}$ vitamin $\mathrm{E} / \mathrm{kg}$ of concentrate and reported lower values of MDA ( $\mathrm{mg} / \mathrm{kg}$ of meat) at 3 and $9 \mathrm{~d}$ of display in experimental treatments than control treatment. However, Leal et al. [68] only observed a significant effect of dosages of $250 \mathrm{mg}$ vitamin $\mathrm{E} / \mathrm{kg}$ feed but higher dosages did not improve lipid oxidation during $14 \mathrm{~d}$ of display. Baldi et al. [56] provided moderated dosages $(285 \mathrm{mg}$ vitamin $\mathrm{E} / \mathrm{kg}$ of feed) during $56 \mathrm{~d}$ and observed lower values of lipid oxidation at $4 \mathrm{~d}$ of display $(0.15 \mathrm{mg} \mathrm{MDA} / \mathrm{kg}$ meat), mainly because the concentration of vitamin $\mathrm{E}$ in muscle was high $(5.1 \mathrm{mg} / \mathrm{kg}$ meat) respect to the control. Finally, Simitzis et al. [69] fed lambs with a dose of $200 \mathrm{mg}$ vita$\mathrm{min} \mathrm{E} / \mathrm{kg}$ feed for $35 \mathrm{~d}$ and reported lower values of lipid oxidation than in control treatment on both fresh and frozen meat.

\section{Polyphenols}

Plant polyphenols are secondary metabolites, which means they are metabolic intermediates or products no essential to plant life but rather required for interaction with the environment (i.e., produced in response to stress). They are classified according to their chemical structure and can be divided into four major classes: phenolic compounds, terpenes, sulphur and nitrogen containing secondary metabolites (as glycosides and alkaloids) [70]. We will focus on the first two groups due to their contrasting potential antioxidant effect on animal metabolism.

A phenolic is a chemical compound characterised by the presence of aromatic ring structure bearing one or more hydroxyl groups. Phenolics range from simple molecules, such as phenolic acid, to highly polymerised substances, such as tannins. Another way of categorising polyphenols is based on the chemical structures of their aglycones, that allow classifying them into four main groups: phenolic acids, flavonoids (isoflavones, isoflavonoids and chalcones, flavones, flavonols, flavanones and flavanonols, flavanols and proanthocyanidins, anthocyanidins), polyphenolic amides and miscellaneous group of non-flavonoid polyphenols (resveratrol, unique to the grapes and red wine, ellagic acid and its derivatives, found in berry fruits and in the skins of different tree nuts, and rosmarinic acid, a dimer of caffeic acid) [71].

\section{Proanthocyanidins}

Proanthocyanidins (PACs) or condensed tannins (common name) are flavonoids formed by oligomers of flavan-3-ol units linked through carbon-carbon bound that resists the hydrolysis and they are the most common type of tannins found especially in the tree of the generous Pinus sp., Acacia sp., Quercus sp., in shrubs such as family of Rosaceae [73] and in forage legumes as sainfoin (Onobrychis viciifolia), sulla (Hedysarum coronarium) and birdsfoot trefoil (Lotus pedunculatus) [74]. They have been incorporated into the diet of sheep and lamb directly as fresh forage or indirectly as plant extracts of forages, for example, rockrose (Cistus ladani$f e r)$, or tree extracts in the concentrate, as quebracho (Schinopsis balansae).

The importance of PACs in ruminant nutrition is attributed to the fact that they can influence intake, production, health and product quality [75, 76]. In addition, they have a great capacity to interact with molecules, having adverse or beneficial effects on productive parameters, depending on their concentration, structure and molecular weight, as well as on the animal species and its physiology [73]. Besides of all these factors mentioned, there is a lack of standardization in the analysis, with special mention to the different standards used to quantify the amount of PAC. It is generally considered that the high content of PAC ( $>50 / \mathrm{kg}$ dry matter) reduce the voluntary feed intake due to a reduction in palatability and digestibility, and consequently negatively affect productive parameters [74, 77].

In the last decades, PAC have been well-studied due to their recorded beneficial effects instead of their negative or anti-nutritive effects. The effect of PACs on growth and meat quality are presented in Table 3 . The results related to the lambs' growth are not conclusive. Studies showed an increase [84, 85], a decrease [86, 87], or no effect [88] on the ADG of lambs.

Concerning the meat colour, the inclusion of $100 \mathrm{~g} / \mathrm{kg}$ $\mathrm{DM}$ of quebracho in the concentrate of the dams diet (70:30 Forage:Concentrate) increased the lightness, yellowness and hue values in the meat of their suckling lamb compared to control on $\mathrm{d} 7$ and 9 of air exposure [78]. Luciano et al. [89] also reported an increase in hue with an inclusion of $70 \mathrm{~g} / \mathrm{kg} \mathrm{DM}$ of quebracho in light lamb concentrate. However, this effect was not observed when the quebracho was included at $50 \mathrm{~g} / \mathrm{kg} D M$ in the concentrate of light lambs [42]. In a recent metaanalysis, taking into account 41 original articles, Álvarez-Rodríguez et al. [90] concluded that the inclusion of PACs did not improve the colour of meat compared with the control.

Another desirable effect of the PACs is their antioxidant capacity [91], ascribed to their scavenging of free radicals, chelating of redox-active metals and inactivating of hemeproteins via reduction of highly pro-oxidant ferryl states [92]. López-Andrés et al. [93] reported that the PACs from quebracho were not absorbed in the 
Table 3 The effect of the inclusion of different sources rich in proanthocyanidins in lamb's diet on antioxidant activity, a-tocopherol and fatty acid profile in meat

\begin{tabular}{|c|c|c|c|c|c|c|c|}
\hline Source & Dietary inclusion level & Lamb type $^{1}$ & $\begin{array}{l}\text { Lambs } \\
\text { growth }^{2}\end{array}$ & $\begin{array}{l}\text { Oxidation, } \\
\text { TBARS }^{2}\end{array}$ & $\begin{array}{l}\text { a-tocopherol } \\
\text { in meat }\end{array}$ & FA profile ${ }^{2}$ & Ref. \\
\hline Quebracho (Schinopsis balansae) & $100 \mathrm{~g} / \mathrm{kg} \mathrm{DM}$ & Suckling & $=$ & $\downarrow(9 \mathrm{~d})$ & $\uparrow$ & $\downarrow$ SFA & {$[41,78]$} \\
\hline Sainfoin (Onobrichis vicifolia) & Ad libitum (grazing) & Light & $=$ & $\downarrow(14 \mathrm{~d})$ & $\uparrow$ & $\begin{array}{l}\uparrow C L A \\
\uparrow n-3 \text { PUFA } \\
\downarrow n-6: n-3\end{array}$ & [42] \\
\hline Rockrose (Cistus ladanifer) ${ }^{3}$ & 50,100 and $200 \mathrm{~g} / \mathrm{kg} \mathrm{DM}$ & Heavy & $=$ & $\downarrow(7 \mathrm{~d})$ & $\uparrow$ & $\begin{array}{l}\downarrow n-6 \text { LC-PUFA } \\
\downarrow n-3 \text { LC-PUFA }\end{array}$ & {$[79,80]$} \\
\hline Mimosa (Acacia mearnsii) extract & $40 \mathrm{~g} / \mathrm{kg} \mathrm{DM}$ & Heavy & $=$ & $=(7 \mathrm{~d})$ & NR & $=$ & [81] \\
\hline Carob pulp (Ceratonia siliqua) & 240 and $350 \mathrm{~g} / \mathrm{kg} \mathrm{DM}$ & Heavy & $=$ & $=(6 \mathrm{~d})$ & NR & $\begin{array}{l}\uparrow n-3 \text { PUFA } \\
\downarrow n-6: n-3\end{array}$ & [82] \\
\hline Quebracho (Schinopsis balansae) & 20 and $40 \mathrm{~g} / \mathrm{kg} \mathrm{DM}$ & Heavy & $\uparrow^{4}$ & NR & NR & $\begin{array}{l}\downarrow \text { SFA } \\
\uparrow C L A \\
\uparrow P U F A^{5}\end{array}$ & [18] \\
\hline Sainfoin (Onobrichis vicifolia) silage & $350 \mathrm{~g} / \mathrm{kg} \mathrm{DM}$ & Heavy & $=$ & $\downarrow(4 \mathrm{~d})$ & $\uparrow$ & $=$ & [83] \\
\hline \multicolumn{8}{|c|}{$\begin{array}{l}\text { CLA Conjugated Linoleic Acid, LC-PUFA Long Chain Polyunsaturated Fatty Acids (sum of } \geq \text { C20), PUFA Polyunsaturated Fatty Acid, SFA Saturated Fatty Acid, } \\
\text { TBARS Thiobarbituric Acid Reactive Substances } \\
{ }^{1} \text { Suckling is a } 30-45 \text { days old lamb with } 12-14 \mathrm{~kg} \text {, light is a } 75-90 \text { days old lamb with } 22-28 \mathrm{~kg} \text {, heavy is a }>120 \text { days old lamb with }>35 \mathrm{~kg} \text { of body-weight } \\
\text { at slaughter } \\
{ }^{2} \text { Arrows indicate up ( } \uparrow \text { ) or down }(\downarrow) \text { significant values compared to control. The almost equal sign (=) symbolize no change between control and } \\
\text { proanthocyanidins-rich diet. TABRS values and days (d) of exposure are expressed } \\
{ }^{3} \text { Effects of the highest dose }(200 \mathrm{~g} / \mathrm{kg} \text { DM) vs. } 50 \text { and } 100 \mathrm{~g} / \mathrm{kg} \mathrm{DM} \\
{ }^{4} \text { Only with an inclusion of } 20 \mathrm{~g} / \mathrm{kg} \\
\end{array}$} \\
\hline
\end{tabular}

gastrointestinal tract of light lambs, but induced antioxidant effects in their plasma and livers. The inclusion of rockrose at 50,100, and $200 \mathrm{~g} / \mathrm{kg}$ DM in the feed in fattening lambs diet did not affect the reducing ability (ferric reducing antioxidant power assay, FRAP) or the radical scavenging ability (trolox equivalent antioxidant capacity assay, TEAC) in muscle, however, the highest inclusion of rockrose showed lower levels of lipid oxidation (TBARS) compared to diets with lower inclusion levels. In this line, Lobón et al. [42] reported a considerable reduction of TBARS in light lambs whose dams grazed sainfoin than lambs whose dams grazed alfalfa or fed indoors a total mixed ratio during lactation, which may also be partly attributed to the increase in vitamin $\mathrm{E}$ content of muscle.

In addition, dietary PACs can modulate ruminal lipid metabolism by negatively affecting some species of fibrolytic bacteria and ciliate protozoa, and inhibit some steps of biohydrogenation of dietary PUFA [94]. Literature shows that the inclusion of PAC in the diet can be useful to improve the FA of meat, however the effect depends on the type of source and the amount intake (Table 3 ).

The inclusion of quebracho in the diet of heavy lambs decreased the total SFA and increased CLA [18] even when the diet was fed to dams and the effect was observed in suckling lambs [78]. An increase of n-3 PUFA content and consequently a decrease of $n-6: n-3$ ratio was observed in light lambs, that were in sainfoin meadows with their dams during lactation compared with lambs-dams in alfalfa meadows or indoors [42], and in heavy lambs with the inclusion of carob pulp (240 and $350 \mathrm{~g} / \mathrm{kg} \mathrm{DM}$ ) in the concentrate [82]. In contrast, Jerónimo et al. [79] reported a decrease of n-6 and n-3 long chain PUFA with the inclusion of $200 \mathrm{~g} / \mathrm{kg}$ DM of rockrose vs. $50 \mathrm{~g} / \mathrm{kg}$ DM without affecting the total PUFA, while other studies reported no effect of FA in heavy lambs with the inclusion of $350 \mathrm{~g} / \mathrm{kg}$ DM of sainfoin silage or $40 \mathrm{~g} / \mathrm{kg} \mathrm{DM}$ of mimosa $[81,83]$. In a recent review, Frutos et al. [128] concluded that PACs can improve the concentration of certain potentially beneficial FA, such as ALA, LA, CLA, CLnA or VA, however they seem to induce smaller increases in other FA (e.g., C18: $1 t 10)$, that might be detrimental to animal performance (i.e., milk fat synthesis) and perhaps human health.

\section{Other phenolic compounds}

Dietary inclusion of antioxidants in animal feed has been proven a more effective strategy to prevent oxidative damage of meat than their direct addition into meat [95]. There are several phenolic compounds extracts with a positive effect on meat stability that may be also considered as animal dietary supplements. Pomegranate pomace and tomato pomace extracts are used directly in the packing to increase the shelf life meat, but synthetic antioxidants (sodium ascorbate), grape and olive pomace aqueous extracts (dose of $1000 \mathrm{mg} / \mathrm{kg}$ of meat) have been recommended as natural additives in minced lamb meat patties, due to higher radical scavenging activity and lower metal chelating activity with respect to the first extracts mentioned [96]. Muiño et al. [97] 
concluded that the red wine extract was more effective as antioxidant in lamb meat patties than direct vitamin $\mathrm{E}$ addition, even when n-3 PUFA content was high. The antioxidant properties of red wine have been related to polyphenolic compounds, which include flavonoids, especially catechins and proanthocyanidins, but also nonflavonoids such as hydroxybenzoic acids, hydroxycinnamic acids, and stilbenes [98]. Generally, research works do not report short-chain phenolic compounds in dietary ingredients and supplements for lambs, which limits its specific association with animal physiology responses. Nowadays, it is accepted that, at least in humans, phenolic compounds can be either absorbed in the small intestine or secreted in bile, or reach the large intestine, where they are susceptible to modification by the microbial population, resulting in microbiota-derived metabolites with potentially beneficial health effects [99].

There is no clear effect of short-chain phenolic compounds on the meat lipid oxidation outcomes, depending on the feed supplements nature, its active molecules, inclusion level and storage conditions (Table 4). Besides, there is an important drawback about the determination of the antioxidant capacity. The wide heterogeneity of the analytical methods is partially responsible for the variability of results related to the inclusion of polyphenols in the diet. A diversity of tests has been developed, as the Folin-Ciocalteu assay, FRAP assay, the TEAC assay, the oxygen radical absorbing capacity (ORAC) assay, DPPH (2,2-diphenyl-1-picrylhydrazyl) radicalscavenging capacity assay, and ABTS $\left(2,2^{\prime}\right.$-azino-bis (3ethylbenzothiazoline- 6-sulfonic acid) substrate peroxidase assay. In this regard, Ortuño et al. [106] found that FRAP and DPPH assays were more suitable than the TEAC assay for predicting meat oxidation and the resulting discolouration and rancidity.

In a recent study, Leal et al. [107] evaluated the effects of supplementation at the level of $5 \mathrm{~g} / \mathrm{kg}$ of feed with either plant extracts from bay (Laurus nobilis), marjoram (Origanum majorana), oregano (Origanum vulgare), rosemary (Rosmarinus officinalis), thyme (Thymus vulgaris), turmeric (Curcuma longa), cumin (Cuminum cyminum), caraway (Carum carvi), dill (Anethum graveolens), cinnamon (Cinnamomum zeylanicum) and nutmeg (Myristica fragans) during 14 d in finishing lambs. These authors observed divergent results on the antioxidant status in the tissues (as assessed by the different methods), that may be either associated with a prooxidant effect of the plant extracts or with the specificity

Table 4 The inclusion of plant extracts or oils rich in miscellaneous polyphenols and lipid oxidation in lamb meat

\begin{tabular}{|c|c|c|c|c|c|c|}
\hline $\begin{array}{l}\text { Lamb } \\
\text { type }\end{array}$ & $\begin{array}{l}\text { Supplement } \\
\text { presentation }\end{array}$ & Feed supplement & $\begin{array}{l}\text { Main attributed active } \\
\text { molecules }\end{array}$ & $\begin{array}{l}\text { Dietary inclusion } \\
\text { level }\end{array}$ & $\begin{array}{l}\text { TBARS differences } \\
\text { compared with control }^{2}\end{array}$ & Ref. \\
\hline Suckling & Plant extract & $\begin{array}{l}\text { Orange (Citrus } \times \text { sinensis }) \\
\text { and lemon }(\text { Citrus } \times \text { limon }) \\
\text { extract }\end{array}$ & $\begin{array}{l}\text { Cyanidin 3-glucoside } \\
\text { Cyanidin 3-(6-malonyl) glucoside } \\
\text { Peonidin 3-(6-malonyl) glucoside }\end{array}$ & $\begin{array}{l}90 \mathrm{mg} / \mathrm{kg} \text { of body- } \\
\text { weight (mixed with } \\
\text { water) }\end{array}$ & $\downarrow$ (7-day refrigerated storage) & [100] \\
\hline Light & $\begin{array}{l}\text { Plant by- } \\
\text { product }\end{array}$ & $\begin{array}{l}\text { Red wine (Vitis vinifera) } \\
\text { extract }\end{array}$ & $\begin{array}{l}\text { Flavonoids } \\
\text { Hydroxybenzoic and } \\
\text { hydroxycinnamic acids } \\
\text { Stilbenes (resveratrol) }\end{array}$ & 900 mg/kg feed & $\begin{array}{l}\text { NS (stored in MAP (70\% O2/ } \\
30 \% \text { CO2) over } 12 \mathrm{~d} \text { at } 4{ }^{\circ} \mathrm{C} \text { ) }\end{array}$ & [101] \\
\hline Light & $\begin{array}{l}\text { Plant by- } \\
\text { product }\end{array}$ & $\begin{array}{l}\text { Pomegranate (Punica } \\
\text { granatum) by-product }\end{array}$ & $\begin{array}{l}\text { Conjugated linolenic acids } \\
\text { (CLnA) } \\
\text { Ellagitannin (hydroxybenzoic } \\
\text { acid) } \\
\text { Flavonoids } \\
\text { a-tocopherol }\end{array}$ & $200 \mathrm{~g} / \mathrm{kg}$ of feed & $\downarrow$ (7-day refrigerated storage) & [102] \\
\hline Heavy & Essential oil & Grape seed (Vitis vinifera) & $\begin{array}{l}\text { Flavonoids (catechins, } \\
\text { epicatechins, trans-resveratrol, } \\
\text { and procyanidin B1) } \\
\text { a-tocopherol } \\
\text { Phytosterols }\end{array}$ & $\begin{array}{l}20 \text { and } 40 \mathrm{~g} / \mathrm{kg} \text { of } \\
\text { feed }\end{array}$ & $\downarrow$ (12-day refrigerated storage) & [103] \\
\hline Heavy & Plant extract & $\begin{array}{l}\text { Yerba mate (Ilex } \\
\text { paraguariensis) extract }\end{array}$ & $\begin{array}{l}\text { Caffeic acid, 5-caffeoylquinic } \\
\text { acid, and rutin. } \\
\text { Alkaloids and saponins. }\end{array}$ & $40 \mathrm{~g} / \mathrm{kg}$ of feed & NS (7-day refrigerated storage) & [104] \\
\hline Heavy & $\begin{array}{l}\text { Plant by- } \\
\text { product }\end{array}$ & $\begin{array}{l}\text { Pomegranate (Punica } \\
\text { granatum) seed cake }\end{array}$ & $\begin{array}{l}\text { Conjugated linolenic acids } \\
\text { (CLnA) } \\
\text { Ellagitannin (hydroxybenzoic } \\
\text { acid) } \\
\text { Punicalagin and gallic acid }\end{array}$ & $\begin{array}{l}115 \text { to } 235 \mathrm{~g} / \mathrm{kg} \text { of } \\
\text { feed }\end{array}$ & $\begin{array}{l}\text { NS up to } 175 \mathrm{~g} / \mathrm{kg} \text { of feed but } \\
\uparrow \text { at } 235 \mathrm{~g} / \mathrm{kg} \text { of feed (1-day } \\
\text { storage) }\end{array}$ & [105] \\
\hline
\end{tabular}

MAP Modified-Atmosphere Package, NS Not Significant, TBARS Thiobarbituric Acid Reactive Substances

${ }^{1}$ Suckling is a $30-45$ days old lamb with $12-14 \mathrm{~kg}$, light is a $75-90$ days old lamb with $22-28 \mathrm{~kg}$, heavy is a $>120$ days old lamb with $>35 \mathrm{~kg}$ of body-weight at slaughter

${ }^{2}$ Unless otherwise stated, refrigerated storage was conducted in polystyrene tray with oxygen-permeable polypropylene film at $4{ }^{\circ} \mathrm{C}$. Any manuscripts detected differences in redness index $\left(a^{*}\right)$ of lamb meat due to feed supplement 
of the different assays. Cinnamon and rosemary plant extracts had the greatest polyphenol content but the antioxidant status of muscle was increased only with nutmeg dietary supplementation. In addition, these authors reported no effect of these plant extracts on growth performance of the lambs, although the length of supplementation period was too short (14 d).

In Mediterranean countries, a valuable source of bioactive phenolic compounds could be the olive (Olea europaea) leaves and cake extracts, that are rich in tyrosol and hydroxytyrosol [108] and oleuropein [109], as they have important antioxidant potential to scavenge free radicals and to avoid chain reactions. Under in vitro conditions, olive leaf was even better antioxidant properties than ascorbic acid on oxygen scavenging, at concentrations over $50 \mu \mathrm{g} / \mathrm{mL}$ of extract [110]. Another food supplement to enhance the shelf life of meat may be the stoned olive cake from oil pressing, that has been included up to $350 \mathrm{~g} / \mathrm{kg}$ in feed to reduce lipid oxidation of light lamb meat [111], although the meat colour attributes were not evaluated in that study. In lamb meat patties, Muiño et al. [108] analysed the effect of adding an olive waste extract $(100,200$ or $400 \mathrm{mg}$ gallic acid equivalents/kg muscle) under high-oxygen modified atmosphere packs storage for up to $9 \mathrm{~d}$ at $4{ }^{\circ} \mathrm{C}$. Addition of the olive waste extract delayed meat discolouration and lipid oxidation without affecting the overall liking score by consumers. However, most of these studies were conducted either with meat patties or did not evaluate voluntary feed intake and growth of lambs, thus, it is necessary to confirm whether these olive or wine co-products may affect animal performance. Olive cake and leafs, and red wine waste extracts may be a good source for the enrichment of the antioxidant characteristics of lamb meat and for the strengthening of circular economy in agroecosystems, although they require previous drying and processing to be used as feed supplements.

\section{Terpenes}

Plant terpenes constitute a large class of natural products which are composed of isoprene units. Vasta et al. [112] detected sesquiterpene volatile compound markers (copaene and $\beta$-caryophyllene) in meat from heavy lambs supplemented with rosemary essential oil (Rosmarinus officinalis), rich in cineole, camphor and pinene, or desert wormwood essential oil (Artemisia herba alba), rich in chrysanthenone, camphor and thujone, at the inclusion level of $400 \mathrm{mg} / \mathrm{kg}$ of feed. In this regard, Serrano et al. [113] observed in beef that terpenes appeared to preferably accumulate in the perirenal and peritoneal fat, and that sesquiterpenes were retained more than monoterpenes or their oxygenated derivatives in the tissues of the calves receiving essential oils.
More recently, Moura et al. [114] demonstrated that dietary supplementation with copaiba (resin) oil (0.5 to $0.75 \mathrm{~g} / \mathrm{kg}$ of feed), that is rich in sesquiterpenes as $\beta$ cariophilene, $\beta$-bisabolene, $\alpha$-humulene, $\beta$-selinene, and $\alpha$-bisabolol, can improve feed efficiency in feedlot heavy lambs with no effect on the meat colour. However, these authors did not evaluate its effect on lipid oxidation of meat. Realini et al. [115] studying the supplementation of heavy lambs with a mix of aromatic spices (lemon albedo, thyme, garlic) (inclusion level of 131 to $157 \mathrm{~g} / \mathrm{kg}$ of feed) did not observe effect on the colour stability of meat but improved their liking scores by consumers, which suggests that plant extracts terpenes may affect the volatile organic compounds in meat, in agreement with the outcomes by Ortuño et al. [116] when adding rosemary diterpenes in light lamb feed.

Red meat cuts, such as lamb, are often packed in high$\mathrm{O}_{2}$ protective atmospheres to maintain their redness for longer without considering the consequent enhancement of lipid oxidation. Rosemary diterpene extracts (rich in carnosic acid and carnosol) (inclusion level of 200 and $400 \mathrm{mg} / \mathrm{kg}$ of feed) contributed to the inhibition of volatile compound formation and rancidity of lamb meat stored under modified atmosphere package (MAP) (70\% $\mathrm{O}_{2} / 30 \% \mathrm{CO}_{2}$ ) during 14d [116]. In a subsequent study, these authors found that rosemary diterpene extracts (inclusion level of $600 \mathrm{mg} / \mathrm{kg}$ of feed) had a lower deposition rate than vitamin $\mathrm{E}$ in lamb muscle and were completely degraded during cooking, thereby being less effective than dietary vitamin $\mathrm{E}$ in enhancing the oxidative stability of the yielded patties [65]. In another recent study, Leal et al. [68] demonstrated that, unlike vitamin $\mathrm{E}$, neither dose nor protection of rosemary extract (embedded in a fat matrix) had an effect on production parameters, lipid oxidation or meat colour stability of lambs during the $14 \mathrm{~d}$ of storage under retail conditions. Accordingly, this may explain that dietary terpenes from rosemary essential oil failed to improve the rumenic acid content of meat $[112,117]$, that was indeed increased with dietary Artemisia essential oil supplementation [112] and grape seed oil supplementation [103]. As plant essential oils may contain not only terpenes but also some minor phenolics, these do not seem to modify rumen biohydrogenation to an extent enough to increase rumenic acid accretion, but they may decrease lipid oxidation in meat during long refrigerated storage (Table 5).

\section{Conclusions}

Supplementation with dietary ALA-rich sources (accounting for 1-4\% of ALA out of total diet composition) increases the content of ALA, n-3 PUFA and decrease n-6/n-3 ratio in muscle, without affecting animal performance, carcass and meat characteristics. Similar results are observed with LA-rich sources, that also 


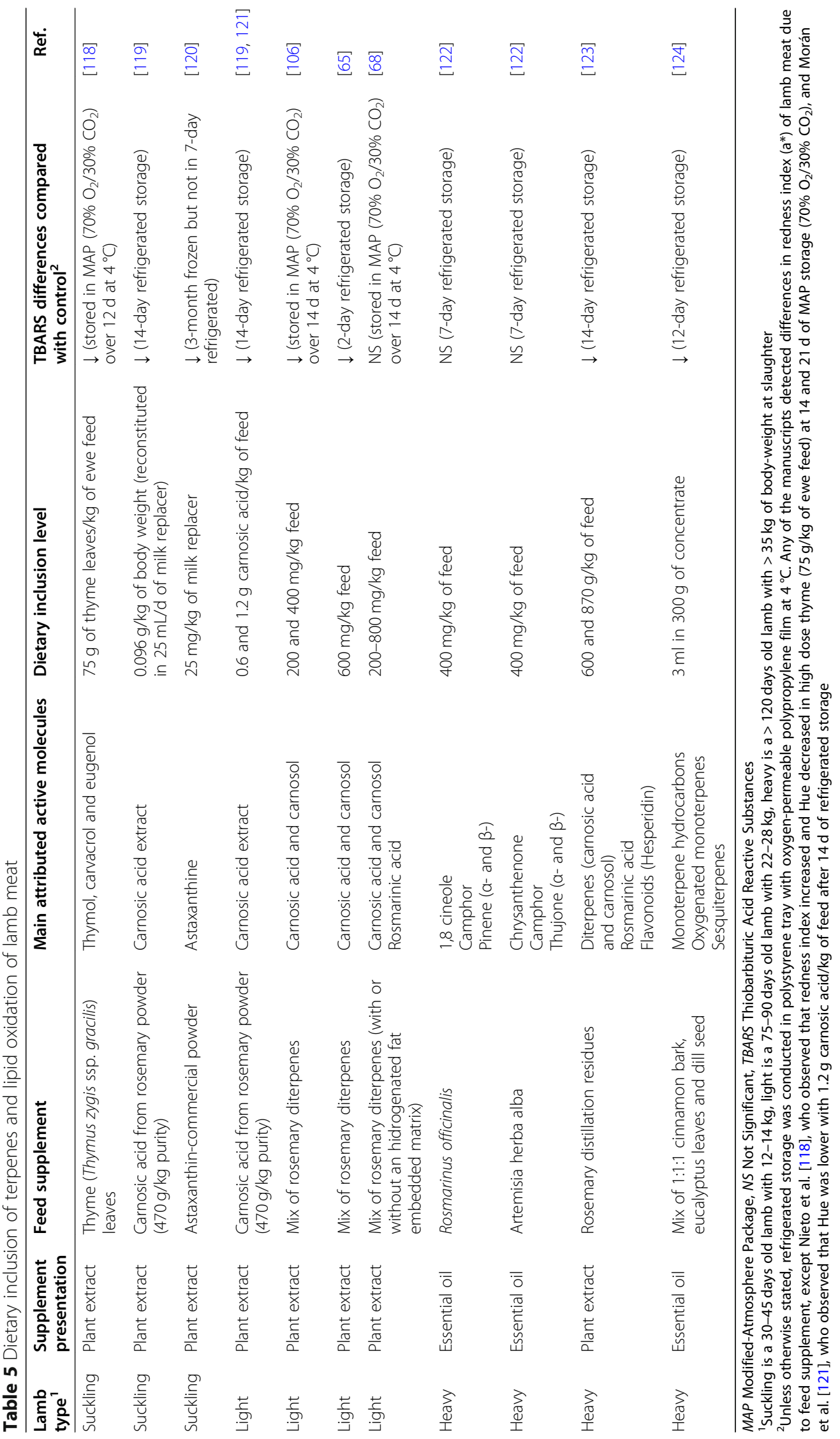


increase LA and RA in meat, although high LA level may have negative effects on lambs' performance and lipid oxidative stability. In contrast, in forage diets (especially fresh) the high dietary ALA and LA content (1-2\% of total diet composition) is probably traded-off by the presence of other bioactive compounds, as vitamin $\mathrm{E}$ (mainly $\alpha$-tocopherol) and polyphenols, that counterbalance the lipid oxidation in meat.

There is a wide consensus on the capability of vitamin E delaying lipid oxidation on lamb meat. Also, it seems there is a plateau of 4 to $5 \mathrm{mg}$ of vitamin $\mathrm{E} / \mathrm{kg}$ of meat, that can be reached with dietary doses of $400 \mathrm{mg}$ of vitamin $\mathrm{E} / \mathrm{kg}$ of feed. It is mandatory to adjust the vitamin $\mathrm{E}$ level in the concentrate and time of feeding to attain optimal concentration of vitamin $\mathrm{E}$ in muscle, but many studies do not provide the concentrate intake by lambs.

A high dietary inclusion of proanthocyanidins, phenolic compounds and terpenes reduce the lipid oxidation in muscle and they may improve the shelf life of lamb meat, probably as a result of a combined effect with dietary vitamin $\mathrm{E}$. However, the recommended dietary inclusion levels depend on the polyphenol concentration and antioxidant capacity of the feedstuffs, that cannot be compared easily because no routine analytical grading methods are yet available. Unless phenolic compounds content in dietary ingredients/supplements for lambs are reported, no specific association with animal physiology responses may be established.

\section{Abbreviations \\ ADG: Average daily gain; ALA: a-Linolenic acid; CLA: Conjugated linoleic acid; DHA: Docosahexaenoic acid; DMI: Dry matter intake; EPA: Eicosapentaenoic acid; Ext. Linseed: Extruded linseed; FA: Fatty acid; IMF: Intramuscular fat; Juic.: Juiciness; LA: Linoleic acid; LC-PUFA: Long chain polyunsaturated fatty acids (sum of $\geq$ C20); LTL: Longissimus Thoracis Et Lumborum; \\ MDA: Malonaldehyde; MAP: Modified-atmosphere package; NR: Not reported; NS: Not significant; OA: Oleic acid; OL: Overall liking; \\ PACs: Proanthocyanidins; PUFA: Polyunsaturated fatty acid; SFA: Saturated fatty acid; RA: Rumenic acid; TBARS: Thiobarbituric acid reactive substances; Tend: Tenderness}

\section{Acknowledgements}

The authors acknowledge the support of Iberus Campus network entitled "Meat production: biodiversity and sustainability".

\section{Authors' contributions}

Conceptualization, JA-R; Investigation, Formal analysis, Writing-Original draft preparation, Reviewing and Editing: OU, SL, GR, JA-R; Reviewing and Editing, JRB; Writing-Reviewing, Editing, Supervision, MJ. All authors read and approved the final manuscript.

\section{Funding}

This review was funded by Ministry of Science, Innovation and Universities of Spain (Grant numbers: INIA RTA2017-00008-C02-01 and-02), and the Technology Transfer Operation of the Rural Development Program of Catalonia 2014-2020 (Government of Catalonia and the European Regional Development Funds, Grant code 01.02.01).

\section{Availability of data and materials}

The datasets used and/or analysed during the current study are available from the corresponding author on reasonable request.

\section{Declarations}

Ethics approval and consent to participate

Not applicable.

\section{Consent for publication}

Not applicable.

\section{Competing interests}

The authors declare that they have no competing interests.

\section{Author details}

${ }^{1}$ Departament de Ciència Animal, Universitat de Lleida, 25198 Lleida, Spain. ${ }^{2}$ Departamento de Agronomía, Biotecnología y Alimentación, IS-FOOD Institute, Escuela Técnica Superior de Ingeniería Agronómica y Biociencias, Universidad Pública de Navarra, Pamplona, Spain. ${ }^{3}$ Centro de Investigación y Tecnología Agroalimentaria de Aragón (CITA), Avda. Montañana 930, 50059 Zaragoza, Spain. ${ }^{4}$ Instituto Agroalimentario de Aragón - IA2

(CITA-Universidad de Zaragoza), Avda. Miguel Servet, 177, 50013 Zaragoza, Spain.

Received: 20 August 2021 Accepted: 7 December 2021

Published online: 07 February 2022

\section{References}

1. Urrutia O, Soret B, Insausti K, Mendizabal JA, Purroy A, Arana A. The effects of linseed or chia seed dietary supplementation on adipose tissue development, fatty acid composition, and lipogenic gene expression in lambs. Small Rumin Res. 2015;123(2-3):204-11. https://doi.org/10.1016/j.sma Ilrumres.2014.12.008

2. Atti N, Methlouthi N, Saidi C, Mahouachi M. Effects of extruded linseed on muscle physicochemical characteristics and fatty acid composition of lambs. J Appl Anim Res. 2013;41(4):404-9. https://doi.org/10.1080/09712119.2013. 792730

3. Woods VB, Fearon AM. Dietary sources of unsaturated fatty acids for animals and their transfer into meat, milk and eggs: A review. Livest Sci. 2009;126(13):1-20. https://doi.org/10.1016/j.livsci.2009.07.002.

4. Innis SM. Dietary omega 3 fatty acids and the developing brain. Brain Res. 2008;1237:35-43. https://doi.org/10.1016/j.brainres.2008.08.078.

5. Jensen $\mathrm{CL}$. Effects of $\mathrm{n}-3$ fatty acids during pregnancy and lactation. Am J Clin Nutr. 2006;83(6):1452S-7S. https://doi.org/10.1093/ajcn/83.6.1452S

6. Toral PG, Monahan FJ, Hervas G, Frutos P, Moloney AP. Review: modulating ruminal lipid metabolism to improve the fatty acid composition of meat and milk. Challenges Oppor Anim. 2018;12(s2):s272-81. https://doi.org/10.1 017/S1751731118001994.

7. Chikwanha OC, Vahmani P, Muchenje V, Dugan MER, Mapiye C. Nutritional enhancement of sheep meat fatty acid profile for human health and wellbeing. Food Res Int. 2018;104:25-38. https://doi.org/10.1016/j.foodres.2 017.05.005.

8. Jiménez P, Masson L, Quitral V. Chemical composition of chia seed, flaxseed and rosehip and its contribution in fatty acids omega-3. Rev Chil Nutr. 2013; 40:155-60.

9. Nguyen DV, Malau-Aduli BS, Cavalieri J, Nichols PD, Malau-Aduli AEO. Supplementation with plant-derived oils rich in omega-3 polyunsaturated fatty acids for lamb production. Vet Anim Sci. 2018;6:29-40. https://doi.org/1 0.1016/j.vas.2018.08.001.

10. Ayerza R, Coates W. Composition of chia (Salvia hispanica) grown in six tropical and subtropical ecosystems of South America. Trop Sci. 2004;44(3): 131-5. https://doi.org/10.1002/ts.154.

11. Madeira MS, Cardoso C, Lopes PA, Coelho D, Afonso C, Bandarra NM, et al. Microalgae as feed ingredients for livestock production and meat quality: A review. Livest Sci. 2017;205:111-21. https://doi.org/10.1016/j.livsci.2017.09.020.

12. Tocher DR, Betancor MB, Sprague M, Olsen RE, Napier JA. Omega-3 longchain polyunsaturated fatty acids, EPA and DHA: bridging the gap between supply and demand. Nutrients. 2019;11(1):1-20. https://doi.org/10.3390/nu11 010089

13. Urrutia O, Mendizabal JA, Insausti K, Soret B, Purroy A, Arana A. Effects of addition of linseed and marine algae to the diet on adipose tissue development, fatty acid profile, lipogenic gene expression, and meat quality in lambs. PLoS One. 2016;11(6):1-23. https://doi.org/10.1371/journal.pone.01 56765. 
14. De la Fuente-Vázquez J, Díaz-Díaz-Chirón MT, Pérez-Marcos C, CañequeMartínez V, Sánchez-González Cl, Álvarez-Acero I, et al. Linseed, microalgae or fish oil dietary supplementation affects performance and quality characteristics of light lambs. Span J Agric Res. 2014;12(2):436-47. https:// doi.org/10.5424/sjar/2014122-4639.

15. Bas $P$, Berthelot $V$, Pottier $E$, Normand J. Effect of level of linseed on fatty acid composition of muscles and adipose tissues of lambs with emphasis on trans fatty acids. Meat Sci. 2007;77(4):678-88. https://doi.org/10.1016/j. meatsci.2007.05.022

16. Miltko R, Majewska MGP, Bełzecki G, Kula K, Kowalik B. Growth performance, carcass and meat quality of lambs supplemented different vegetable oils. Asian-Australas J Anim Sci. 2019;32(6):767-75. https://doi.org/10.5713/ajas.18. 0482.

17. Noci F, Monahan FJ, Moloney AP. The fatty acid profile of muscle and adipose tissue of lambs fed camelina or linseed as oil or seeds. Animal. 2011;5(1):134-47. https://doi.org/10.1017/S1751731110001485.

18. Kamel HEM, Al-Dobaib SN, Salem AZM, López S, Alaba PA. Influence of dietary supplementation with sunflower oil and quebracho tannins on growth performance and meat fatty acid profile of Awassi lambs. Anim Feed Sci Technol. 2018;235:97-104. https://doi.org/10.1016/j.anifeedsci.201 7.11.006.

19. Boles JA, Kott RW, Hatfield PG, Bergman JW, Flynn CR. Supplemental safflower oil affects the fatty acid profile, including conjugated linoleic acid, of lamb. J Anim Sci. 2005;83(9):2175-81. https://doi.org/10.2527/2005.83921 $75 x$.

20. Ferreira MS, Goes RHTB, Martinez AC, Gandra JR, Fernandes ARM, Gonçales WA, et al. Safflower seeds in the diet of feedlot lambs improved fat carcass, colour, and fatty acid profile of the meat. South Afr J Anim Sci. 2019;49(5): 922-33. https://doi.org/10.4314/sajas.v49i5.16.

21. Oliveira ER, Gandra JR, Monção FP, Gabriel AMA, Fernandes ARM, Góes RHT, et al. High levels of sunflower crushed in diets for feedlot lambs depress the performance and carcass quality. Iran J Appl Anim Sci. 2018;8(2):221-9.

22. Díaz MT, Pérez C, Sánchez Cl, Lauzurica S, Cañeque V, González C, et al. Feeding microalgae increases omega 3 fatty acids of fat deposits and muscles in light lambs. J Food Compos Anal. 2017;56:115-23. https://doi. org/10.1016/j.jfca.2016.12.009.

23. Parvar R, Ghoorchi T, Shargh MS. Influence of dietary oils on performance, blood metabolites, purine derivatives, cellulase activity and muscle fatty acid composition in fattening lambs. Small Rumin Res. 2017;150:22-9. https://doi.org/10.1016/j.smallrumres.2017.03.004.

24. Hopkins DL, Clayton EH, Lamb TA, Van de Ven RJ, Refshauge G, Kerr MJ, et al. The impact of supplementing lambs with algae on growth, meat traits and oxidative status. Meat Sci. 2014;98(2):135-41. https://doi.org/10.1016/j. meatsci.2014.05.016.

25. Fan $Y$, Ren C, Meng F, Deng K, Zhang G, Wang F. Effects of algae supplementation in high-energy dietary on fatty acid composition and the expression of genes involved in lipid metabolism in Hu sheep managed under intensive finishing system. Meat Sci. 2019;157:107872. https://doi. org/10.1016/j.meatsci.2019.06.008.

26. Manso T, Bodas R, Castro T, Jimeno V, Mantecon AR. Animal performance and fatty acid composition of lambs fed with different vegetable oils. Meat Sci. 2009;83(3):511-6. https://doi.org/10.1016/j.meatsci.2009.06.035.

27. Facciolongo AM, Lestingi A, Colonna MA, Nicastro F, De Marzo D, Toteda F. Effect of diet lipid source (linseed vs. soybean) and gender on performance, meat quality and intramuscular fatty acid composition in fattening lambs. Small Rumin Res. 2018;159:11-7. https://doi.org/10.1016/j.smallrumres.201 7.11.015.

28. Quiñones J, Maggiolino A, Bravo S, Muñoz E, Lorenzo JM, Cancino D, et al. Effect of canola oil on meat quality and fatty acid profile of Araucano creole lambs during fattening period. Anim Feed Sci Technol. 2019;248:20-6. https://doi.org/10.1016/j.anifeedsci.2018.12.002

29. Jaworska D, Czauderna M, Przybylski W, Rozbicka-Wieczorek AJ. Sensory quality and chemical composition of meat from lambs fed diets enriched with fish and rapeseed oils, carnosic acid and seleno-compounds. Meat Sci. 2016;119:185-92. https://doi.org/10.1016/j.meatsci.2016.05.003.

30. Nute GR, Richardson RI, Wood JD, Hughes SI, Wilkinson RG, Cooper SL, et al. Effect of dietary oil source on the flavour and the colour and lipid stability of lamb meat. Meat Sci. 2007;77(4):547-55. https://doi.org/10.1016/j.mea tsci.2007.05.003

31. Kott RW, Hatfield PG, Bergman JW, Flynn CR, Van Wagoner $H$, Boles JA. Feedlot performance, carcass composition, and muscle and fat CLA concentrations of lambs fed diets supplemented with safflower seeds. Small Rumin Res. 2003;49(1):11-7. https://doi.org/10.1016/S0921-4488(03 )00052-X

32. Urrutia O, Mendizabal JA, Alfonso L, Soret B, Insausti K, Arana A. Adipose tissue modification through feeding strategies and their implication on adipogenesis and adipose tissue metabolism in ruminants. Int J Mol Sci. 2020;21(9):3183. https://doi.org/10.3390/ijms21093183.

33. De Brito GF, Holman BWB, McGrath SR, Friend MA, van de Ven R, Hopkins $D L$. The effect of forage-types on the fatty acid profile, lipid and protein oxidation, and retail colour stability of muscles from white Dorper lambs. Meat Sci. 2017;130:81-90. https://doi.org/10.1016/j.meatsci.2017.04.001.

34. Amaral AB, Solva MVD, Lannes SCDS. Lipid oxidation in meat: mechanisms and protective factors - a review. Food Sci Technol. 2018;38(suppl 1):1-15. https://doi.org/10.1590/fst.32518.

35. Kouba M, Mourot J. A review of nutritional effects on fat composition of animal products with special emphasis on $\mathrm{n}-3$ polyunsaturated fatty acids. Biochimie. 2011;93(1):13-7. https://doi.org/10.1016/j.biochi.2010.02.027.

36. Vatansever L, Kurt E, Enser M, Nute GR, Scollan ND, Wood JD, et al. Shelf life and eating quality of beef from cattle of different breeds given diets differing in $n-3$ polyunsaturated fatty acid composition. Anim Sci. 2000;71(3): 471-82. https://doi.org/10.1017/S135772980005548X.

37. Sekali M, Marume U, Mlambo V, Strydom PE. Growth performance, hematology, and meat quality characteristics of mutton merino lambs fed canola-based diets. Trop Anim Health Prod. 2016;48(6):1115-21. https://doi. org/10.1007/s11250-016-1058-x

38. Buendía-Rodríguez G, Vallejo LH, Elghandour MMY, Salem AZM, Mlambo V. Effect of dietary inclusion of safflower meal on ruminal fermentation, growth performance, carcass characteristics, and meat quality of lambs. Can J Anim Sci. 2019;99(2):260-7. https://doi.org/10.1139/cjas-2018-0096.

39. Lima AGVdO, Oliveira RL, Nascimiento TVC, Martins A, Costa TV, da Silva V, et al. Feeding sunflower cake from biodiesel production to Santa Ines lambs: Physicochemical composition, fatty acid profile and sensory attributes of meat. PLoS One 2018;13:1-14.

40. Glasser F, Doreau M, Maxin G, Baumont R. Fat and fatty acid content and composition of forages: A meta-analysis. Anim Feed Sci Tech. 2013;185(1-2): 19-34. https://doi.org/10.1016/j.anifeedsci.2013.06.010.

41. Lobón S, Joy M, Sanz A, Álvarez-Rodríguez J, Blanco M. The fatty acid composition of ewe milk or suckling lamb meat can be used to discriminate between ewes fed different diets. Anim Prod Sci. 2019;59(6): 1108-18. https://doi.org/10.1071/AN18082.

42. Lobón S, Blanco M, Sanz A, Ripoll G, Bertolín JR, Joy M. Meat quality of light lambs is more affected by the dam's feeding system during lactation than by the inclusion of quebracho in the fattening concentrate1. J Anim Sci. 2017;95(11):4998-5011. https://doi.org/10.2527/jas2017.1595.

43. Willems $\mathrm{H}$, Kreuzer M, Leiber F. Alpha-linolenic and linoleic acid in meat and adipose tissue of grazing lambs differ among alpine pasture types with contrasting plant species and phenolic compound composition. Small Rumin Res. 2014;116(2):153-64. https://doi.org/10.1016/j.smallrumres.2013.11. 002.

44. Girard M, Dohme-Meier F, Silacci P, Kragten SA, Kreuzer M, Bee G. Forage legumes rich in condensed tannins may increase n-3 fatty acid levels and sensory quality of lamb meat. J Sci Food Agric. 2016;96(6):1923-33. https:// doi.org/10.1002/jsfa.7298.

45. Sattler SE, Cheng Z, DellaPenna D. From Arabidopsis to agriculture: engineering improved vitamin E content in soybean. Trends Plant Sci. 2004; 9(8):365-7. https://doi.org/10.1016/j.tplants.2004.06.002.

46. Bekhit AE-DA, Hopkins DL, Fahri FT, Ponnampalam EN. Oxidative processes in muscle systems and fresh meat: sources, markers, and remedies. Compr Rev Food Sci Food Saf. 2013;12(5):565-97. https://doi.org/10.1111/1541-433 7.12027.

47. Lauzurica S, de la Fuente J, Díaz MT, Álvarez I, Pérez C, Cañeque V. Effect of dietary supplementation of vitamin $\mathrm{E}$ on characteristics of lamb meat packed under modified atmosphere. Meat Sci. 2005;70(4):639-46. https:// doi.org/10.1016/j.meatsci.2005.02.013.

48. Bellés M, del Mar CM, Roncalés $P$, Beltrán JA. Supranutritional doses of vitamin E to improve lamb meat quality. Meat Sci. 2019;149:14-23. https:// doi.org/10.1016/j.meatsci.2018.11.002.

49. Pinto APP, Furusho-Garcia IF, Leopoldino Júnior I, Olalquiaga Pérez JR, Alves NG, Pereira IG. Performance and carcass characteristics of lambs fed diets with fat and vitamin E. Rev Bras Zootec. 2011;40(12):2911-21.37. https://doi. org/10.1590/S1516-35982011001200039. 
50. Bezerra HVA, Gallo SB, Rosa AF, Fernandes AC, e Silva S da L, Leme PR. Impact of purified lignin on performance, rumen health, oxidative stress control and meat quality of lambs fed a high-concentrate diet. Livest Sci. 2020;231:103882.

51. Torres-Geraldo A, Sartori-Bueno M, da Costa RL-D, Harada-Haguiwara MM, Regina-Cucatti M, Gomes-da-Silva M, et al. Effect of castration and vitamin E supplementation on carcass and meat quality of Santa Inês lambs. Rev Colomb Cienc Pecu. 2020;33(2):96-109. https://doi.org/10.17533/udea.rccp. v33n2a02.

52. Hampel V da S, Poli CHEC, Devincenzi T, Pötter L. Feeding systems and tocopherol level in the diet and their effects on the quality of lamb meat: a meta-analysis. Rev Bras Zootec. 2019;48:e20180223. https://doi.org/10.1590/ rbz4820180223.

53. Guidera J, Kerry JP, Buckley DJ, Lynch PB, Morrissey PA. The effect of dietary vitamin $\mathrm{E}$ supplementation on the quality of fresh and frozen lamb meat. Meat Sci. 1997;45(1):33-43. https://doi.org/10.1016/S0309-1740(96)00086-1.

54. NRC. Nutrient requirements of sheep (Vol. 5). Washington: National Academies Press; 1985

55. Jose CG, Jacob RH, Pethick DW, Gardner GE. Short term supplementation rates to optimise vitamin $\mathrm{E}$ concentration for retail colour stability of Australian lamb meat. Meat Sci. 2016;111:101-9. https://doi.org/10.1016/j. meatsci.2015.08.006.

56. Baldi G, Chauhan SS, Linden N, Dunshea FR, Hopkins DL, Sgoifo Rossi CA, et al. Comparison of a grain-based diet supplemented with synthetic vitamin E versus a lucerne (alfalfa) hay-based diet fed to lambs in terms of carcass traits, muscle vitamin E, fatty acid content, lipid oxidation, and retail colour of meat. Meat Sci. 2019;148:105-12. https://doi.org/10.1016/j.mea tsci.2018.10.013.

57. Holman BWB, Baldi G, Chauhan SS, Hopkins DL, Seymour GR, Dunshea FR, et al. Comparison of grain-based diet supplemented with synthetic vitamin E and lucerne hay-based diet on blood oxidative stress biomarkers and lamb meat quality. Small Rumin Res. 2019;177:146-52. https://doi.org/10.101 6/j.smallrumres.2019.05.016.

58. Kasapidou E, Wood JD, Richardson RI, Sinclair LA, Wilkinson RG, Enser M. Effect of vitamin E supplementation and diet on fatty acid composition and on meat colour and lipid oxidation of lamb leg steaks displayed in modified atmosphere packs. Meat Sci. 2012;90(4):908-16. https://doi.org/10.1016/j. meatsci.2011.11.031.

59. López-Bote CJ, Daza A, Soares M, Berges E. Dose-response effect of dietary vitamin E concentration on meat quality characteristics in light-weight lambs. Anim Sci. 2001;73(3):451-7. https://doi.org/10.1017/S1357729800058422.

60. Álvarez I, la Fuente JD, Díaz MT, Lauzurica S, Pérez C, Cañeque V. Estimation of a-tocopherol concentration necessary to optimise lamb meat quality stability during storage in high-oxygen modified atmosphere using brokenline regression analysis. Animal. 2008;2(9):1405-11. https://doi.org/10.1017/ S1751731108002590.

61. Ponnampalam EN, Norng S, Burnett VF, Dunshea FR, Jacobs JL, Hopkins DL. The synergism of biochemical components controlling lipid oxidation in Lamb muscle. Lipids. 2014;49(8):757-66. https://doi.org/10.1007/s11745-014-3916-5.

62. de Almeida FA, Sobrinho AG da S, Manzi GM, Lima NLL, Endo V, Zeola $\mathrm{NMBL}$, et al. Dietary supplementation with sunflower seeds and vitamin $\mathrm{E}$ for fattening lambs improves the fatty acid profile and oxidative stability of the longissimus lumborum. Anim Prod Sci. 2014;55(8):1030-6.

63. González-Calvo L, Ripoll G, Molino F, Calvo JH, Joy M. The relationship between muscle a-tocopherol concentration and meat oxidation in light lambs fed vitamin E supplements prior to slaughter. J Sci Food Agric. 2015; 95(1):103-10. https://doi.org/10.1002/jsfa.6688.

64. Ripoll G, Joy M, Muñoz F. Use of dietary vitamin E and selenium (se) to increase the shelf life of modified atmosphere packaged light lamb meat. Meat Sci. 2011:87(1):88-93. https://doi.org/10.1016/..meatsci.2010.09.008.

65. Ortuño J, Inchingolo R, Delgado P, Cardenia V, Rodriguez-Estrada MT, Jordán MJ, et al. Enhancing lipid oxidative stability of cooked-chilled Lamb meat through dietary rosemary Diterpenes. Eur J Lipid Sci Technol. 2020; 122(3):1900124. https://doi.org/10.1002/ejlt.201900124.

66. Bellés $M$, Alonso $V$, Roncalés $P$, Beltrán JA. Display stability of fresh and thawed lamb supplemented with vitamin $\mathrm{E}$ or sprayed with an antioxidant borage seed extract. J Sci Food Agric. 2018;98(8):2871-9. https://doi.org/10.1002/jsfa.8780.

67. Bellés $M$, Leal LN, Díaz $V$, Alonso $V$, Roncalés $P$, Beltrán JA. Effect of dietary vitamin $E$ on physicochemical and fatty acid stability of fresh and thawed lamb. Food Chem. 2018;239:1-8. https://doi.org/10.1016/j. foodchem.2017.06.076
68. Leal LN, Beltrán JA, Bellés M, Bello JM, den Hartog LA, Hendriks WH, et al. Supplementation of lamb diets with vitamin $\mathrm{E}$ and rosemary extracts on meat quality parameters. J Sci Food Agric. 2020;100(7):2922-31. https://doi. org/10.1002/jsfa.10319.

69. Simitzis PE, Charismiadou MA, Goliomytis M, Charalambous A, Ntetska I,

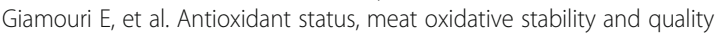
characteristics of lambs fed with hesperidin, naringin or a-tocopheryl acetate supplemented diets. J Sci Food Agric. 2019;99(1):343-9. https://doi. org/10.1002/jsfa.9193.

70. Pagare S, Bhatia M, Tripathi N, Pagare S, Bansal YK. Secondary metabolites of plants and their role: overview. Curr Trends Biotechnol Pharm. 2015;9(3): 293-304.

71. Tsao R. Chemistry and biochemistry of dietary polyphenols. Nutrients. 2010; 2(12):1231-46. https://doi.org/10.3390/nu2121231.

72. Turner KE, McClure KE, Weiss WP, Borton RJ, Foster JG. Alpha-tocopherol concentrations and case life of lamb muscle as influenced by concentrate or pasture finishing1. J Anim Sci. 2002;80(10):2513-21. https://doi.org/10.1 093/ansci/80.10.2513.

73. Piluzza G, Sulas L, Bullitta S. Tannins in forage plants and their role in animal husbandry and environmental sustainability: a review. Grass Forage Sci. 2014;69(1):32-48. https://doi.org/10.1111/gfs.12053.

74. Frutos P, Hervás G, Giráldez F, Mantecón ÁR. Review. Tannins and ruminant nutrition. Spanish J Agric Res. 2004;2(2):191-202. https://doi.org/10.5424/sja $r / 2004022-73$

75. Min BR, Barry TN, Attwood GT, McNabb WC. The effect of condensed tannins on the nutrition and health of ruminants fed fresh temperate forages: a review. Anim Feed Sci Technol. 2003;106(1):3-19. https://doi.org/1 0.1016/S0377-8401(03)00041-5.

76. Vasta $V$, Luciano $G$. The effects of dietary consumption of plants secondary compounds on small ruminants' products quality. Small Rumin Res. 2011; 101(1):150-9. https://doi.org/10.1016/j.smallrumres.2011.09.035.

77. Waghorn G. Beneficial and detrimental effects of dietary condensed tannins for sustainable sheep and goat production-Progress and challenges. Anim Feed Sci Technol. 2008;147(1):116-39. https://doi.org/10.1016/j.anifeedsci.2 007.09.013.

78. Lobón S, Sanz A, Blanco M, Ripoll G, Joy M. The type of forage and condensed tannins in dams' diet: influence on meat shelf life of their suckling lambs. Small Rumin Res. 2017;154:115-22. https://doi.org/10.1016/j. smallrumres.2017.08.005.

79. Jerónimo E, Soldado D, Sengo S, Francisco A, Fernandes F, APV P, et al. Increasing the a-tocopherol content and lipid oxidative stability of meat through dietary Cistus ladanifer $L$ in lamb fed increasing levels of polyunsaturated fatty acid rich vegetable oils. Meat Sci. 2020;164:108092. https://doi.org/10.1016/j.meatsci.2020.108092.

80. Francisco A, Dentinho MT, Alves SP, Portugal PV, Fernandes F, Sengo S, et al. Growth performance, carcass and meat quality of lambs supplemented with increasing levels of a tanniferous bush (Cistus ladanifer L.) and vegetable oils. Meat Sci. 2015;100:275-82. https://doi.org/10.1016/j. meatsci.2014.10.014.

81. Biondi L, Randazzo CL, Russo N, Pino A, Natalello A, Van Hoorde K, et al. Dietary supplementation of tannin-extracts to lambs: effects on meat fatty acids composition and stability and on microbial characteristics. Foods. 2019;8(10):469. https://doi.org/10.3390/foods8100469.

82. Gravador RS, Luciano G, Jongberg S, Bognanno M, Scerra M, Andersen ML, et al. Fatty acids and oxidative stability of meat from lambs fed carobcontaining diets. Food Chem. 2015;182:27-34. https://doi.org/10.1016/j. foodchem.2015.02.094.

83. Luciano G, Natalello A, Mattioli S, Pauselli M, Sebastiani B, Niderkorn V, et al. Feeding lambs with silage mixtures of grass, sainfoin and red clover improves meat oxidative stability under high oxidative challenge. Meat Sci. 2019;156:59-67. https://doi.org/10.1016/j.meatsci.2019.05.020.

84. Dawson LER, McCoy MA, Edgar HWJ, Carson AF. Effect of concentrate supplementation at pasture and inclusion of condensed tannins (Quebracho) in concentrates on lamb performance and faecal egg and worm counts. Livest Sci. 2011;135(2):205-14. https://doi.org/10.1016/j.livsci.2 010.07.006.

85. Hart KJ, Sinclair LA, Wilkinson RG, Huntington JA. Effect of whole-crop pea (Pisum sativum L.) silages differing in condensed tannin content as a substitute for grass silage and soybean meal on the performance, metabolism, and carcass characteristics of lambs1. J Anim Sci. 2011;89(11): 3663-76. https://doi.org/10.2527/jas.2009-2617. 
86. Valenti B, Natalello A, Vasta V, Campidonico L, Roscini V, Mattioli S, et al. Effect of different dietary tannin extracts on lamb growth performances and meat oxidative stability: comparison between mimosa, chestnut and tara. Animal. 2019;13(2):435-43. https://doi.org/10.1017/S1751731118001556.

87. Vasta V, Priolo A, Scerra M, Hallett KG, Wood JD, Doran O. $\Delta 9$ desaturase protein expression and fatty acid composition of longissimus dorsi muscle in lambs fed green herbage or concentrate with or without added tannins. Meat Sci. 2009;82(3):357-64. https://doi.org/10.1016/j.meatsci.2009.02.007.

88. Lobón S, Pascua AS, Alibés MB, Torrens MJ. Efecto del tipo de forraje y la inclusión de quebracho en la dieta de ovejas lactantes sobre sus rendimientos productivos. ITEA Inf Téc Económica Agrar Rev Asoc Interprofesional Para El Desarro Agrar AIDA. 2017;113(4):359-75. https://doi. org/10.12706/itea.2017.023.

89. Luciano G, Vasta V, Monahan FJ, López-Andrés P, Biondi L, Lanza M, et al. Antioxidant status, colour stability and myoglobin resistance to oxidation of longissimus dorsi muscle from lambs fed a tannin-containing diet. Food Chem. 2011;124(3):1036-42. https://doi.org/10.1016/j.foodchem.2010.07.070.

90. Álvarez-Rodríguez J, Villalba D, Molina E, Serrano-Pérez B, Bertolín JR, Joy M. Do dietary condensed tannins affect the growth performance, fatty acid composition and lamb meat colour? ITEA. 2020;116(2):116-30.

91. Hagerman AE, Riedl KM, Jones GA, Sovik KN, Ritchard NT, Hartzfeld PW, et al. High molecular weight plant polyphenolics (tannins) as biological antioxidants. J Agr Food Chem. 1998;46(5):1887-92. https://doi.org/10.1021/ jf970975b.

92. Iglesias J, Pazos M, Torres $\lrcorner$, Medina I. Antioxidant mechanism of grape procyanidins in muscle tissues: redox interactions with endogenous ascorbic acid and a-tocopherol. Food Chem. 2012;134(4):1767-74. https:// doi.org/10.1016/j.foodchem.2012.03.072.

93. López-Andrés P, Luciano G, Vasta V, Gibson TM, Biondi L, Priolo A, et al. Dietary quebracho tannins are not absorbed, but increase the antioxidant capacity of liver and plasma in sheep. Br J Nutr. 2013;110(4):632-9. https:// doi.org/10.1017/S0007114512005703.

94. Vasta V, Daghio M, Cappucci A, Buccioni A, Serra A, Viti C, et al. Invited review: plant polyphenols and rumen microbiota responsible for fatty acid biohydrogenation, fiber digestion, and methane emission: experimental evidence and methodological approaches. J Dairy Sci. 2019;102(5):3781-804. https://doi.org/10.3168/jds.2018-14985.

95. Kerry JP, Buckley DJ, Morrissey PA, O'Sullivan K, Lynch PB. Endogenous and exogenous a-tocopherol supplementation: effects on lipid stability (TBARS) and warmed-over flavour (WOF) in porcine M. longissimus dorsi roasts held in aerobic and vacuum packs. Food Res Int. 1998;31(3):211-6. https://doi. org/10.1016/S0963-9969(98)00068-4

96. Andrés Al, Petrón MJ, Adámez JD, López M, Timón ML. Food by-products as potential antioxidant and antimicrobial additives in chill stored raw lamb patties. Meat Sci. 2017;129:62-70. https://doi.org/10.1016/j.meatsci.2017.02.013.

97. Muíño I, de la Fuente J, Pérez C, Apeleo E, Pérez-Santaescolástica C, Cañeque $V$, et al. Use of red wine polyphenols as a natural preservative in health-promoting Omega-3 fatty acids-enriched Lamb patties. Molecules. 2018;23(12):3080. https://doi.org/10.3390/molecules23123080.

98. Surai PF. Polyphenol compounds in the chicken/animal diet: from the past to the future. J Anim Physiol Anim Nutr. 2014;98(1):19-31. https://doi.org/1 $0.1111 /$ jpn. 12070 .

99. Marhuenda-Muñoz M, Laveriano-Santos EP, Tresserra-Rimbau A, LamuelaRaventós RM, Martínez-Huélamo M, Vallverdú-Queralt A. Microbial phenolic metabolites: which molecules actually have an effect on human health? Nutrients. 2019;11(11):2725. https://doi.org/10.3390/nu11112725.

100. Maggiolino A, Bragaglio A, Salzano A, Rufrano D, Claps S, Sepe L, et al. Dietary supplementation of suckling lambs with anthocyanins: effects on growth, carcass, oxidative and meat quality traits. Anim Feed Sci Technol. 2021;276:114925. https://doi.org/10.1016/j.anifeedsci.2021.114925.

101. Muíño I, Apeleo E, de la Fuente J, Pérez-Santaescolástica C, Rivas-Cañedo A, Pérez C, et al. Effect of dietary supplementation with red wine extract or

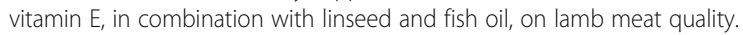
Meat Sci. 2014;98(2):116-23. https://doi.org/10.1016/j.meatsci.2014.05.009.

102. Natalello A, Priolo A, Valenti B, Codini M, Mattioli S, Pauselli M, et al. Dietary pomegranate by-product improves oxidative stability of lamb meat. Meat Sci. 2020;162:108037. https://doi.org/10.1016/j.meatsci.2019.108037.

103. Sharifi M, Bashtani M, Naserian AA, Farhangfar H, Rasani M, Emami A. Grape seed oil supplementation in lamb diet: effect on meat oxidation stability and muscle fatty acids. Ital J Anim Sci. 2019;18(1):1302-9. https://doi.org/1 $0.1080 / 1828051 \times .2019 .1645622$
104. Pena-Bermudez YA, Lobo RR, Rojas-Moreno DA, Poleti MD, de Amorim TR, Rosa $A F$, et al. Effects of feeding increasing levels of yerba mate on Lamb meat quality and antioxidant activity. Animals. 2020;10(9):1458. https://doi. org/10.3390/ani10091458.

105. Kotsampasi B, Christodoulou C, Mavrommatis A, Mitsiopoulou C, Bampidis VA, Christodoulou V, et al. Effects of dietary pomegranate seed cake supplementation on performance, carcass characteristics and meat quality of growing lambs. Anim Feed Sci Technol. 2021;273:114815. https://doi. org/10.1016/j.anifeedsci.2021.114815.

106. Ortuño J, Serrano R, Jordán MJ, Bañón S. Relationship between antioxidant status and oxidative stability in lamb meat reinforced with dietary rosemary diterpenes. Food Chem. 2016;190:1056-63. https://doi.org/10.1016/j. foodchem.2015.06.060.

107. Leal LN, Jordán MJ, Bello JM, Otal J, den Hartog LA, Hendriks WH, et al. Dietary supplementation of 11 different plant extracts on the antioxidant capacity of blood and selected tissues in lightweight lambs. J Sci Food Agric. 2019;99(9):4296-303. https://doi.org/10.1002/jsfa.9662.

108. Muíño I, Díaz MT, Apeleo E, Pérez-Santaescolástica C, Rivas-Cañedo A, Pérez

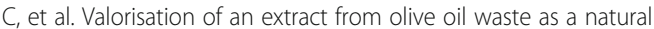
antioxidant for reducing meat waste resulting from oxidative processes. J Clean Prod. 2017;140:924-32. https://doi.org/10.1016/j.jclepro.2016.06.175.

109. Rey Al, de-Cara A, Calvo L, Puig P, Hechavarría T. Changes in plasma fatty acids, free amino acids, antioxidant defense, and physiological stress by oleuropein supplementation in pigs prior to slaughter. Antioxidants. 2020;9(1):56.

110. Lins PG, Marina Piccoli Pugine S, Scatolini AM, de Melo MP. In vitro antioxidant activity of olive leaf extract (Olea europaea L.) and its protective effect on oxidative damage in human erythrocytes. Heliyon. 2018;4(9):e00805.

111. Luciano G, Pauselli M, Servili M, Mourvaki E, Serra A, Monahan FJ, et al. Dietary olive cake reduces the oxidation of lipids, including cholesterol, in lamb meat enriched in polyunsaturated fatty acids. Meat Sci. 2013;93(3): 703-14. https://doi.org/10.1016/j.meatsci.2012.11.033.

112. Vasta V, Aouadi D, Brogna DMR, Scerra M, Luciano G, Priolo A, et al. Effect of the dietary supplementation of essential oils from rosemary and artemisia on muscle fatty acids and volatile compound profiles in Barbarine lambs. Meat Sci. 2013;95(2):235-41. https://doi.org/10.1016/j. meatsci.2012.12.021.

113. Serrano E, Cornu A, Kondjoyan N, Figueredo G, Agabriel J, Micol D. Terpene accumulation in muscle and fatty tissues of calves supplemented with essential oils. J Anim Feed Sci. 2007;16(2):168-79. https://doi.org/10.22358/ja fs/66736/2007.

114. Moura LV, Oliveira ER, Fernandes ARM, Gabriel AMA, Silva LHX, Takiya CS, et al. Feed efficiency and carcass traits of feedlot lambs supplemented either monensin or increasing doses of copaiba (Copaifera spp.) essential oil. Anim Feed Sci Technol. 2017;232:110-8.

115. Realini CE, Bianchi G, Bentancur O, Garibotto G. Effect of supplementation with linseed or a blend of aromatic spices and time on feed on fatty acid composition, meat quality and consumer liking of meat from lambs fed dehydrated alfalfa or corn. Meat Sci. 2017;127:21-9. https://doi.org/10.1016/j. meatsci.2016.12.013.

116. Ortuño J, Serrano R, Bañón S. Use of dietary rosemary diterpenes to inhibit rancid volatiles in lamb meat packed under protective atmosphere. Animal. 2016;10(8):1391-401. https://doi.org/10.1017/S1751731116000392.

117. Smeti S, Hajji H, Mekki I, Mahouachi M, Atti N. Effects of dose and administration form of rosemary essential oils on meat quality and fatty acid profile of lamb. Small Rumin Res. 2018;158:62-8. https://doi.org/10.101 6/j.smallrumres.2017.10.007.

118. Nieto G, Díaz P, Bañón S, Garrido MD. Effect on lamb meat quality of including thyme (Thymus zygis ssp. gracilis) leaves in ewes' diet. Meat Sci. 2010;85(1):82-8. https://doi.org/10.1016/j.meatsci.2009.12.009.

119. Morán L, Andrés S, Mateo J, Blanco C, Soto S, Giráldez FJ. Effect of dietary carnosic acid on meat quality from suckling lambs. Small Rumin Res. 2014; 121(2):314-9. https://doi.org/10.1016/j.smallrumres.2014.08.003.

120. Carballo DE, Giráldez FJ, Andrés S, Caro I, Fernández-Gutiérrez M, Mateo J. Effects of dietary astaxanthin supplementation on the oxidative stability of meat from suckling lambs fed a commercial milk-replacer containing butylated hydroxytoluene. Meat Sci. 2019;156:68-74. https://doi.org/10.1016/ j.meatsci.2019.03.020.

121. Morán L, Rodríguez-Calleja JM, Bodas R, Prieto N, Giráldez FJ, Andrés S. Carnosic acid dietary supplementation at $0.12 \%$ rates slows down meat discoloration in gluteus medius of fattening lambs. Meat Sci. 2012;90(3): 789-95. https://doi.org/10.1016/j.meatsci.2011.11.016. 
122. Aouadi D, Luciano G, Vasta V, Nasri S, Brogna DMR, Abidi S, et al. The antioxidant status and oxidative stability of muscle from lambs receiving oral administration of Artemisia herba alba and Rosmarinus officinalis essential oils. Meat Sci. 2014;97(2):237-43. https://doi.org/10.1016/j.meatsci.2 014.02.005.

123. Yagoubi Y, Joy M, Ripoll G, Mahouachi M, Bertolín JR, Atti N. Rosemary distillation residues reduce lipid oxidation, increase alpha-tocopherol content and improve fatty acid profile of lamb meat. Meat Sci. 2018;136:239. https://doi.org/10.1016/j.meatsci.2017.10.007.

124. Ranucci D, Branciari R, Cobellis G, Acuti G, Miraglia D, Olivieri O, et al. Dietary essential oil mix improves oxidative stability and hygienic characteristic of lamb meat. Small Rumin Res. 2019;175:104-9. https://doi. org/10.1016/j.smallrumres.2019.04.012.

125. Ortuño J, Serrano R, Bañón S. Antioxidant and antimicrobial effects of dietary supplementation with rosemary diterpenes (carnosic acid and carnosol) vs vitamin $\mathrm{E}$ on lamb meat packed under protective atmosphere. Meat Sci. 2015;110:62-9. https://doi.org/10.1016/..meatsci.2015.07.011.

126. Calnan HB, Jacob RH, Pethick DW, Gardner GE. Dietary vitamin E supplementation reduces lamb meat browning on display following up to 70 days of chilled storage. Livest Sci. 2019;230:103843. https://doi.org/10.101 6/j.livsci.2019.103843.

127. Jose CG, Jacob RH, Pethick DW, Gardner GE. A supply chain approach to improving the shelf life of lamb meat; vitamin E concentration, electrical stimulation, ageing period and packaging system. Meat Sci. 2018;139:65-73. https://doi.org/10.1016/j.meatsci.2018.01.005.

128. Frutos P, Hervás G, Natalello A, Luciano G, Fondevila M, Priolo A, et al. Ability of tannins to modulate ruminal lipid metabolism and milk and meat fatty acid profiles. Anim Feed Sci Technol. 2020;269:114623. https://doi.org/1 0.1016/j.anifeedsci.2020.114623.

Ready to submit your research? Choose BMC and benefit from:

- fast, convenient online submission

- thorough peer review by experienced researchers in your field

- rapid publication on acceptance

- support for research data, including large and complex data types

- gold Open Access which fosters wider collaboration and increased citations

- maximum visibility for your research: over $100 \mathrm{M}$ website views per year

At BMC, research is always in progress.

Learn more biomedcentral.com/submissions 